\title{
PATRIOS POLITEIA: ENTRE GOLPES OLIGÁRQUICOS A ANCESTRALIDADE DA DEMOCRACIA SE CONSTRÓI
}

Prof. Dr. Luis Fernando Telles D’Ajello ${ }^{1}$

\begin{abstract}
Resumo: Este trabalho tem por objetivo a análise do processo histórico que leva ao desenvolvimento de uma consciência democrática em Atenas no final do século $\mathrm{V}$ a.C. Para isto observa o desenrolar de uma disputa política entre oligarcas e seus opositores, associado ao desejo do fim da guerra do Peloponeso que era almejado pela maioria dos atenienses, mas por motivos diversos. Durante este processo há uma disputa pela autoridade das propostas dos grupos concorrentes. Esse critério gira em torno da ancestralidade da constituição ateniense indicada por cada grupo. As argumentações que procuram justificar a ancestralidade de suas propostas levam a um entrelaçamento com o processo do desenvolvimento do conceito de democracia. Desta confluência surge o desenvolvimento de uma consciência democrática entre os opositores dos oligarcas extremistas, os demotikoi.

Palavras-chave: Democracia; Constituição Ancestral; Atenas Clássica; Oligarquia.
\end{abstract}

Apesar de favorecidos por Prometeu, os homens se assemelham mais com seu irmão, Epimeteu. Sem a capacidade de previsão é comum se agarrar às chances de, ao menos, saber-se depois. $\mathrm{O}$ conhecimento a partir de um indício conhecido se torna uma baliza para o desvelamento de outros anteriores. No entanto, há de se ter cautela com o quanto se prioriza o marco que guia a investigação, pois este pode influenciar as leituras. As ações dos grupos envolvidos nos embates políticos de 411 e de 404 parecem tão erráticas que muitas concessões e emendas nas fontes têm sido propostas para se encontrar sentido. $\mathrm{O}$ resultado destes embates foi uma democracia com definições tão claras em sua organização e instituições, como em seus procedimentos para promulgação de leis e decretos, e das respectivas peculiaridades destas formas de publicações legais. Estas definições passaram a formar a concepção de uma democracia ancestral dentre os helenos do século IV. Apesar de suas definições serem recentes, uma tradição se construiu em torno desta encarnação da democracia. É possível que, ao vislumbrar esta democracia tão familiar, os 
helenistas procurem nos eventos anteriores os passos que levaram a este desfecho. Esta investigação não é, em si, problemática. No entanto, esperar tirar sentido de açóes que expliquem o direcionamento para este fim pode encobrir momentos de confusão, mudanças de intenções ou mesmo um plano diverso que por causa de suas consequências abriu caminho para este desfecho, mesmo que não intencionalmente.

Em 4 de Maio de 1971, em sua palestra inaugural em Cambridge, Moses Finley expressou muitas destas preocupações e questionamentos de maneira maestral. Este artigo pretende evitar o que Butterfield (1944) ${ }^{2}$ e Finley (1971) chamaram de a sublime e poderosa des-bistoricidade que pode vir junto com a investigação crítica. Ao mesmo tempo evita a procura de uma origem, que no uso popular, como Marc Bloch (2002, p. 56-57) aponta, é “(...) um começo que explica. Pior ainda: que basta para explicar". Aqui se apresenta então uma investigação sobre as diversas motivações e eventos que, independentes entre si, formam o panorama onde a consciência democrática veio a tocar o espírito dos atenienses, a ponto de nomeá-la em contraposição específica aos "atos injustos dos governantes na oligarquia (...)”3 (LÍSIAS, Contra uma Acusação de Subversão da Democracia, 27) ${ }^{4}$

Mesmo entre os antigos atenienses três grupos eram identificados neste período. Suas ações, no entanto, parecem ser por vezes díspares com uma disposição entre oligarcas e democratas. Como se apresentam nas relações pessoais, para além das relações entre os grupos, os interesses parecem mais voltados para o fim da guerra, com discordâncias nas formas de se conseguir este fim. O debate político sobre o controle da polis não é combativo quando do início do que se chama de golpe oligárquico dos Quatrocentos, nem mesmo quando do estabelecimento dos Trinta Tiranos. São as ações destes, quando abusando de seu poder, que causam dificuldades e crises no âmbito político de Atenas. Houve uma ideia que parece concentrar o espírito do período em seu desejo pelo fim da situação contemporânea em prol de um exemplo como dos antigos atenienses. A patrios politeia parece um exemplo da similaridade entre os três grupos envolvidos. As ações de membros específicos destes grupos devem elucidar as motivações gerais dos atenienses e como as consequências de suas decisões levaram a um ambiente de oposição a homens representando uma organização oligárquica da polis. A formação desta oposição consolidou o que costuma se chamar de democracia ateniense do período clássico, mas

2 Citado em Finley.

3 Todas as traduções de Lísias baseadas no grego como estabelecido em LAMB, 1930.

4 Discurso presente no Corpus Lysiacum, mas atualmente tido como espúrio. Produzido em 399. 
que melhor define a democracia do século IV, como estabelecida neste período de stasis.

Os brados, pelo retorno à uma constituição ancestral, surgem durante os eventos que levam ao governo dos Quatrocentos e dos Trinta Tiranos. Para melhor compreender o que instiga os atenienses do fim do século $\mathrm{V}$ a evocarem uma ancestralidade que possa ser melhor do que a organização política de seu tempo, deve-se analisar os precedentes para estes eventos.

\section{INGREDIENTES PARA UMA CRISE ATENIENSE}

Inscrições de diversos tipos surgem em Atenas desde 725 a.C..$^{5}$ Muitos dipinti e graffiti, dedicações e abecedários. Mas inscrições de leis e decretos produzidas pela polis têm uma curva de crescimento em sua produção um tanto diferenciada destas inscrições populares. Apenas três inscrições deste tipo para o século VI e 244 para o século V. Destas 244 temos uma do período das Guerras Pérsicas, 21 entre 475 e 450, 64 de 450 a 425 e 94 entre 425 e $400 .{ }^{6}$ Este claro aumento em inscrições na segunda metade e, principalmente, no último quarto do século está fortemente associado ao desenvolvimento do chamado império ateniense a partir de Péricles. Mas o que esta pesquisa aponta é sua relação próxima com os golpes oligárquicos que se seguem ao desastre da expedição à Sicília.

A partir da metade do século $\mathrm{V}$ os atenienses se concentraram na reconstrução de alguns templos e no erigir de novos. Os gastos com a acrópole somados aos gastos com o desenvolvimento da marinha ateniense só podem ser explicados com a tomada do tesouro da liga de Delos durante o período em que Péricles foi continuamente eleito general. Blamire (2001) sugere que, após os 3800 talentos gastos com a tentativa de se evitar a defecção de Potidéia, 8300 dos 9700 talentos do tesouro da liga teriam sido gastos até 431. Este é o período de ascensão de Atenas como um "Império" impulsionado por homens como Péricles, que ficou mais de 25 anos contínuos como um dos dez generais de Atenas.

Em 429, Péricles é derrotado pela peste que assolou Atenas. Mas dois anos antes instigou os atenienses ao conflito com os peloponésios que levou à Guerra do Peloponeso. Mesmo com sua morte o ímpeto de governar os

5 Todas as datas aqui presentes são referentes a "antes de Cristo", e, portanto, não mais será utilizada esta sigla para facilitar o fluxo de leitura.

6 Para estes números e a análise dos mesmos ver Stoddart \& Whitley (1988), Liddel (2010), Sickinger (1999), e IG I³ (Lewis; Jeffery \& Erxleben, 1981). 
helenos e levar a cabo o caráter de "escola da Hélade" (TUCÍDIDES, História da Guerra do Peloponeso, II, 41) não foi apagado. Mesmo após um acordo que levou à chamada Paz de Nícias os gastos com a elevação da acrópole em um exemplo da altivez ateniense continuaram. Foram efetuadas as construções do Erecteion. Há indícios de que em 409 ainda estava incompleto, mas foi terminado nos anos seguintes. ${ }^{7} \mathrm{O}$ novo prédio para acomodar a Boule, o Bouleuterion, foi terminado entre 415 e 405 (CAMP, 2001), período este em que o antigo Bouleuterion provavelmente passou a ser utilizado como arquivo público de leis, o primeiro na história da Grécia. Ainda assim, a paz e a manutenção do império, através das contribuições anuais de seus "aliados", foi suficiente para completar boa parte dos projetos para a acrópole e ainda formar uma reserva de algo em torno de 6000 talentos por volta de 416 .

Talvez por causa desta situação os atenienses tenham se sentido seguros para tentar expandir o império para a Magna Grécia. Em 415 Egesta, uma polis na Sicília, entra em conflito com a polis de Selinus. Seus cidadãos pedem auxílio, confiando em antigo acordo com Atenas. Uma série de debates ocorre em Atenas até a decisão de se invadir a Sicília. Anos antes Atenas havia declarado uma aliança com Egesta. Sua intenção, de acordo com Tucídides, era dominar toda a Sicília, se opondo principalmente aos siracusanos. Este pedido de auxílio se tornou o pretexto para tal expansão do império ateniense. Nícias, um dos strategoi e autor do tratado de paz com Esparta, tentou dissuadir os atenienses lembrando do perigo de uma quebra do tratado. Alcibíades, outro dos strategoi, instigava Atenas à invasão. ${ }^{8}$ Com a organização da invasão à Sicília por parte dos atenienses os Siracusanos pedem auxílio a Corinto e Esparta.

A expedição sofre perdas, mas a assembleia julga necessário o envio de reforços. Estes chegam a um gasto de 3500 talentos dos 6000 talentos em reserva na época (BLAMIRE, 2001). Todos os atenienses enviados foram mortos ou escravizados e levados a trabalharem em minas. Ostwald (1986, p. 337 n.1) e Andrewes (1992) apontam que dos 45 a 50 mil homens apenas dois generais e sete mil soldados sobreviveram como prisioneiros. Com a perda de todas as naus enviadas, cerca de dois terços da frota ateniense, não restaram mais do que 100 navios à Atenas. Amemiya (2007, p. 36.) propóe uma estimativa de 30 a 60 mil homens adultos, cidadãos, para a população de Atenas em 431, apenas 15 anos antes. Neste desastre pelo menos metade da população dos cidadãos parece ter sido dizimada. Entre os mortos estariam até 200 dos homens de posses a bordo das trirremes como trierarcas.

$7 \mathrm{IG} \mathrm{I}^{3} 474 \mathrm{e} \mathrm{IG} \mathrm{I}^{3} 476$.

8 Os livros sexto e sétimo da obra de Tucídides são dedicados à Sicília. 
É importante notar que nos dias anteriores à partida da expedição as hermai ${ }^{9}$ foram mutiladas. Com isso, um grande alvoroço tomou conta de Atenas. Com indícios de que esta profanação, afrontando ao deus dedicado à proteção aos caminhos e viagens, fosse propositadamente efetuada para trazer malefícios à expedição, uma investigação inicial foi feita. Alcibíades estava entre os suspeitos. Mesmo assim ele partiu para liderar a expedição. Além da destruição das hermai houve a profanação dos ritos de Elêusis. ${ }^{10} \mathrm{Em}$ meio à investigação foi sugerido por Pisandro que havia por trás o interesse em se fazer um golpe oligárquico. Com estas revelações, e o acumulo de acusações sobre Alcibíades, este foi chamado de volta à Atenas para ser julgado. Alcibíades, no entanto, fugiu e se exilou entre os espartanos.

Durante o período da expedição à Sicília, entre 415 e 413, Tucídides relata que Alcibíades teria aconselhado os Espartanos a tomar o forte de Deceléia, ao norte de Atenas (TUCÍDIDES, História da Guerra do Peloponeso, VI, 91-93; LÍSIAS, Contra Alcibíades I, 30). Devido à posição de Deceléia, em relação às montanhas da Ática, a melhor rota para Atenas passava pelo forte. Nada mais vindo da Eubóia chegaria a Atenas com os Espartanos permanentemente estacionados em Deceléia.

Mais uma perda importante para os atenienses ocorreu neste período e esteve relacionada à Deceléia. Mais de vinte mil escravos fugiram de Atenas refugiando-se no forte sob proteção espartana. A estimativa de Amemiya (2007) para os escravos é pouco precisa, mas girava entre 30 e 100 mil escravos. Pelo menos um quinto destes teriam fugido durante o desastre da Sicília.

Frente aos desastres militares, a invasão espartana ao território ático, a defasagem econômica causada por esta situação e o impedimento de chegada de recursos via terra por causa da tomada de Deceléia, os atenienses resolveram revisar as decisóes do demos. Claramente uma série de desfeitas para os deuses, as enormes perdas financeiras, materiais e humanas, sugerem um período em que não só os generais, mas toda a população que tomava decisão nas assembleias deveria estar em choque com a brusca mudança de situação. Um grupo de dez homens, possivelmente um de cada tribo, foi escolhido para revisar as decisões tomadas pelo povo. Este colegiado de probouloi (TUCÍDIDES, História da Guerra do Peloponeso, VII, 1.3) deveria ser composto por

\footnotetext{
9 Blocos de pedra retangulares com a cabeça de Hermes no topo e seu falo no meio. Serviam como marcos de divisóes da cidade e estradas e como símbolo apotropaico.

10 A principal fonte para estes eventos são Tucídides e Andócides. O orador em especial foi um dos acusados e fez uma defesa em seu próprio nome em 399 onde relata detalhadamente estes eventos.
} 
homens de pelo menos 40 anos (ARISTÓTELES, Constituição dos Atenienses, 29.2) e parece ter sido estabelecido pela ekklesia, com poderes de convocar uma reunião da assembleia e de verificar as decisões da ekklesia e da Boule. ${ }^{11}$ Dois destes dez homens são nomeados nas fontes disponíveis atualmente. Sófocles ${ }^{12}$, o tragediógrafo, e Hagnon, pai de Teramênes e strategos junto com Péricles em seus anos finais (LÍSIAS, Contra Eratóstenes, 65; DEVELIN, 1989). Aristóteles (Política, IV.15, 1299b.36-38) sugere que a presença concomitante dos probouloi e da ekklesia seria um resultado tendendo para a oligarquia, pois um conselho de dez é mais oligárquico que a ekklesia. ${ }^{13}$ No entanto, esta afirmação fica comprometida quando se analisam as relações que ambos, Sófocles e Hagnon, tiveram com Péricles. Até mesmo Lísias, franco opositor à figura do filho de Hagnon, apresenta o antigo companheiro de Péricles sob uma luz fortemente democrática. ${ }^{14}$

Neste período também é produzida uma comédia de Eupolis chamada Demoi. Esta comédia, que chegou aos dias de hoje apenas em fragmentos, trata da utilização de magia para ressuscitar quatro grandes nomes da história ateniense para ajudar a polis no período em que se encontra, pois todos os líderes militares e a administração da cidade são muito incompetentes. Lisístrata, de Aristófanes, também ocorre neste período. Todas estas ações e comédias sugerem que após o desastre da expedição à Sicília os atenienses estavam relutantes a seguir, tomando decisões do mesmo modo, intempestivamente. É possível que uma revisão na forma de administração da polis não fosse algo tão longe da mente dos cidadãos atenienses neste momento. Ademais, o cargo dos probouloi é atestado dois anos depois de sua formação em 413, sugerindo um cargo temporário que se alongou pelo menos até a formação dos Quatrocentos. Em 411, o decreto de Pitódoros adiciona vinte homens aos 10 probouloi existentes para que as patrioi nomoi pudessem ser investigadas. Esta manutenção para além de um ano é incomum e pode indicar uma necessidade de fiscalização na tomada de decisões pós Sicília que ia para além de uma

11 Ver OSTWALD, 1986, p. 338-340; GOMME; ANDREWES; DOVER, 1981, p. 6, 165 , 213; RHODES, 1981, p. 372-373.

12 Sófocles fora eleito strategos em 441/0 e 423/22, além de belenotamiai em 443/4. Jameson (1971) sugere que o tragediógrafo parece ter sido próximo de Péricles, mas sem definir a intensidade desta proximidade, referindo-se principalmente ao período em que ambos foram strategoi juntos.

13 Afirmação reiterada por Ostwald (1986, p. 340).

14 Hagnon parece ter estabelecido a colônia de Amphipolis. Ele também assinou a paz de Nícias e a aliança com esparta em 421. Ver LÍSIAS. Contra Eratóstenes, 65; DEVELIN, 1989 e OSTWALD, 1986. 
preocupação momentânea. ${ }^{15}$ Algum debate sobre uma solução permanente pode ser deduzida para este período. Ostwald (1986, p. 343) lembra que apesar dos atenienses terem desenvolvido instituições democráticas, nem os atenienses, nem cidadãos de outra polis, tinham desenvolvido uma teoria política, nem mesmo sobre um governo oligárquico. Entre o debate dos persas de Heródoto, as críticas imaturas de Pseudo-Xenofonte a as críticas às instituições pelos sofistas, não havia consolidação de teorias políticas, fossem democráticas ou oligárquicas. Neste momento, os atenienses procuram pela patrios politeia, patrioi nomoi ou outros tipos de patria. Não apenas "democratas", mas oligarcas também, precisavam dar roupagens do passado para que suas ideias fossem melhor recebidas.

Em 412/11, com dois terços de sua frota dizimada, mais de 35 mil homens a menos após o desastre da Sicília, as reservas de dinheiro praticamente exauridas e uma sensação de dúvida sobre a capacidade de tomada de decisões dos mais importantes corpos administrativos da polis, a procura por uma solução advinda do passado tradicional já era sugerida pela existência dos probouloi e por peças como a de Eupolis.

Diversos aliados de Atenas saem da Liga e alguns chegam a passar para a Liga do Peloponeso. Alcibíades, exilado em Esparta e servindo de conselheiro aos lacedemônios, é enviado pelos espartanos para negociar com Tissafernes, Sátrapa persa responsável pela Jônia. Tissafernes faz dois acordos com o Lacedemônios se comprometendo a auxiliar financeiramente na guerra contra os atenienses. Em comunicação com alguns homens influentes, entre eles trierarcas, estacionados em Samos Alcibíades incitou a reformulação da constituição ateniense para uma mais oligárquica em troca de apoio por parte dos persas. Na situação de Atenas o desejo pelo fim dos desastres pode muito bem ter prevalecido e a sugestão de um auxílio dos persas visto como uma salvação merecedora de atenção, a quase qualquer custo.

\section{Os Quatrocentos e A oposição}

Há, sobre estes eventos, duas fontes com detalhamentos que devem ser consideradas. O livro VIII de Tucídides e a Athenaion Politeia de Aristóteles. Deve-se lembrar que Tucídides, ex-strategos exilado de Atenas, conhecia pessoalmente alguns dos envolvidos, mas que tende a imprimir nestas personagens sua interpretação dos eventos. Aristóteles apresenta um relato mais breve e Rhodes (1981) e Andrewes (1981) sugerem que seja 
altamente baseado no relato de Tucídides. Apenas duas divergências causam certa dificuldade em assimilar ambos os relatos diretamente: o número de syngrapheis e a quantidade de reuniões ocorridas no processo de instauração dos Quatrocentos.

A maior parte da frota ateniense se encontrava estacionada em Samos em 412. Com oito dos dez generais e 74 trirremes presentes no local, podese estimar que em torno de 1500 atenienses se encontravam nesta base de operações para as investidas na Jônia. Alcibíades, em negociaçóes com Tissafernes, troca mensagens com alguns homens estacionados em Samos sugerindo que poderia persuadir os persas a auxiliar os Atenienses caso sua organização política fosse mais favorável aos persas. Tucídides não só apresenta os eventos como sugere as motivações de Alcibíades. É importante aqui notar quem estaria em comunicação com Alcibíades e teria feito parte das organizações para formar uma organização mais oligárquica e, portanto, mais aprazível aos olhos dos persas. Tucídides usa os termos beltisto ${ }^{16} \mathrm{e}$ dynatotato $i$ ao caracterizar os homens contatados por Alcibíades. Certamente, os strategoi presentes e os trierarcas podem facilmente ser considerados tanto bestistoi como dynatoi.

Apesar de Alcibíades fazer propostas a favor de uma oligarquia aos beltistoi e dynatotatoi, há breve menção em Tucídides (VIII, 47.2) de que estes homens influentes já estavam confabulando para a derrubada da democracia. Não há registros dos participantes destas reunióes. No entanto, há pelo menos 12 nomes conhecidos e atrelados aos atenienses estacionados em Samos. Strombiquides, Diómedon e Léon são generais neste momento e aparecem mais tarde como opositores aos oligarcas. Léon pode ser identificado como um dos homens assassinados pelos Trinta Tiranos em 404 e que atuou como general em 406/5, após o segundo exílio de Alcibíades. Neste período Diómedon também atuou como general novamente. No entanto, foi executado pelo demos quando dos eventos de Arginusa. Strombiquides se opôs à paz com Esparta em 404/3 e eventualmente foi executado pelos Trinta Tiranos (TUCÍDIDES, História da Guerra do Peloponeso, VIII,15-79; XENOFONTE. Helênicas, I.5.16; XENOFONTE. Helênicas, I.5.29; LÍSIAS, Contra Agóratos,13; LÍSIAS, Contra Nicômacos, 14).

Euctemon é um general em Samos, mas esta é a única informação conhecida sobre ele (TUCÍDIDES, História da Guerra do Peloponeso, VIII, 30.1). Onômacles, general em Samos, foi um dos embaixadores enviados pelos Quatrocentos para negociar a paz com Esparta. Por causa deste evento 
foi acusado por Andron ${ }^{17}$ junto com Antifonte e Arqueptolemus após a queda dos Quatrocentos, durante o regime intermediário. Ademais, esteve entre os Trinta Tiranos em 404 (XENOFONTE. Helênicas, II, 3.2; TUCÍDIDES, História da Guerra do Peloponeso, VIII, 25). Scironides foi um general que atuou com Frínicus e acompanhava suas decisões militares. Charminus foi requisitado pelos Quatrocentos a assassinar Hyperbolus como prova de sua aliança com os oligarcas (TUCÍDIDES, História da Guerra do Peloponeso, VIII, 73.3). Frínicus foi um dos homens influentes que se opôs ao retorno de Alcibíades. No entanto, após os dynatoi e beltistoi desistirem de seguir os conselhos de Alcibíades e tentarem angariar auxilio dos Persas sem este intermédio, Frínicus se aliou aos mesmos a ponto de se tornar conhecido como líder dos extremistas. Esta pecha levou ao seu assassínio quando do processo da queda dos Quatrocentos (TUCÍDIDES, História da Guerra do Peloponeso, VIII, 68.3; ARISTÓFANES, Rãs, 689; LÍSIAS, Contra uma Acusação de Subversão da Democracia, 9). Trásicles era um oficial em Samos e foi um signatário da paz de Nícias, mas nada mais é conhecido deste personagem. Pisandro é uma figura curiosa entre este grupo. Um dos investigadores dos eventos acerca das mutilações da hermai em 415 e, portanto, com algum reconhecimento popular. Foi escolhido como o porta-voz dos oligarcas e antes de partir para Atenas chamou uma assembleia que foi feita em Samos para deixar a todos a par dos planos e angariar aliados entre os marinheiros e soldados. As fontes sugerem que Pisandro não revelou tudo o que se pretendia fazer, mas dissera que seria vantajoso para a vitória ateniense o retorno de Alcibíades e uma flexibilização na constituição ateniense para receber ajuda dos Persas. A assembleia foi favorável ao discurso de Pisandro. Os soldados e marinheiros em Samos aquiesceram à proposta como apontada por ele. A decisão por modificar a forma de governo, apesar de não explicitamente de forma oligárquica, não foi recusada de início. A vantagem sobre os inimigos parece ter sido o maior motivador neste momento.

Entre os instigadores do movimento contra os Quatrocentos que apareceria meses depois em Samos estavam Trásilus e Trasíbulos. Ambos devem ter participado desta assembleia. No entanto passam, posteriormente, a defender uma forma diferente de organizar a polis e vencer sobre os inimigos. Frente aos relatos de que grupos de partidários de Pisandro estavam aterrorizando Atenas, inclusive com o assassinato de opositores à mudança proposta, Léon e Diómedon se aliam ao trierarca Trasíbulos e ao hoplita Trásilus. Pouco se sabe sobre a vida prévia de Trásilus, mas desde sua posição como instigador dos marinheiros em Samos suas atividades como General 
levam a acreditar que o demos o reconhecia como um aliado. Apesar desta posição foi um dos generais executados pelo demos nos eventos seguindo a vitória de Arginusa. Trasíbulos, um trierarca, foi estabelecido pela assembleia de Samos como um strategos junto a Trásilus. Teve diversas participações na guerra contra Esparta até seu fim, e foi considerado como o líder dos demotikoi quando organizou um grupo de exilados a atacar os Trinta Tiranos e levar à queda deste grupo oligárquico.

Em assembleia em Samos os "homens influentes", dentre eles vários trierarcas, decidiram por manter o plano de mudar a constituição e chamar Alcibíades. Enviaram então Pisandro e outros homens, não nomeados por Tucídides, para Atenas.

Em reunião da ekklesia, Pisandro apresentou a proposta de chamar Alcibíades e "adotarmos uma política mais sábia e entregarmos os cargos públicos a um número mais restrito de pessoas, (..) mais tarde poderemos fazer mudanças se algo nos desgostar" (TUCÍDIDES; KURY, 2001), (TUCÍDIDES, História da Guerra do Peloponeso, VIII, 53). Apesar das oposições, as ideias propostas por Pisandro eram de difícil contra argumentação.

(...) os peloponésios já não possuíam menos naus que os atenienses para enfrentá-los no mar e dominavam mais cidades aliadas do que eles, e o Rei e Tissafernes forneciam dinheiro ao inimigo, enquanto os atenienses já não tinham onde obter recursos, a não ser que alguém persuadisse o Rei a passar para o seu lado. (...) Pois isto só será (...) se em nossas deliberações dermos agora mais atenção à nossa salvação que à nossa forma de governo (mais tarde poderemos fazer mudanças se algo nos desgostar). (TUCÍDIDES; KURY, 2001. pág. 507.)

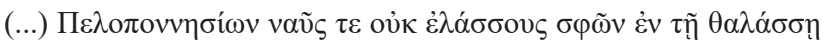

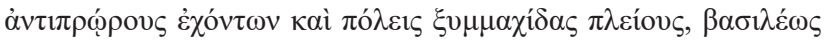

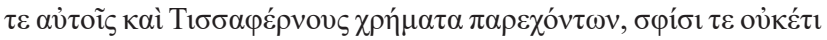

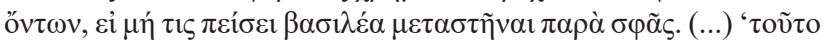

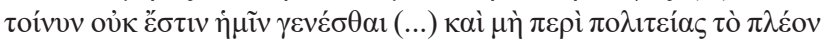

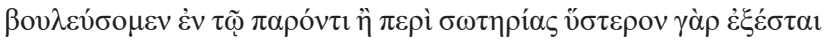

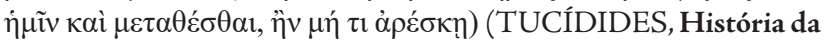
Guerra do Peloponeso, VIII, 53.2-3).

Apesar de alguma oposição, inclusive das duas famílias responsáveis pelos mistérios de Elêusis, profanados por Alcibíades, decidiu-se pelo envio de Pisandro e outros dez para negociar com Tissafernes e Alcibíades. Tucídides ainda afirma que Pisandro entrou em contato com hetaireiai, grupos, clubes, 
de jovens que pensavam como ele e os incitou a agirem em prol da instauração da oligarquia.

As negociações entre Pisandro, Alcibíades e Tissafernes não foram bem sucedidas e os atenienses saíram da satrápia sem o apoio persa. Pisandro passou em Samos e reuniu-se com os outros instigadores da oligarquia ali estacionados. Decidiram por abandonar Alcibíades e tentarem por eles mesmos conseguir o favor dos Persas, momento no qual Frínicus se junta novamente com o grupo.

Em Tucídides (VIII, 65), o historiador apresenta o retorno de Pisandro à Atenas. Lá encontra uma polis aterrorizada por assassinatos de pessoas influentes entre o demos e pessoas opostas ao retorno de Alcibíades. De acordo com Tucídides estas ações foram resultado das intervenções das hetaireiai. Ao fim do capítulo ainda afirma que:

já havia sido apresentada abertamente uma moção no sentido de que somente receberiam salários da cidade aqueles que estivessem servindo na guerra, e que não mais de cinco mil cidadãos participariam do governo; estes deveriam ser os mais qualificados para servir, por suas posses e qualidades pessoais. (TUCÍDIDES; KURY, 2001) (TUCÍDIDES, História da Guerra do Peloponeso, VIII, 65.3)

Pisandro e seus colegas organizaram uma assembleia e decidiram que um grupo de dez syngrapheis ${ }^{18}$ seria estabelecido para propor novas leis. Em uma segunda reunião, agora em Colonos, em um santuário de Poseidon a dois quilômetros de Atenas, apresentaram a proposta de abolir todos os cargos e pagamento para cargos públicos. Ainda propuseram estabelecer um conselho de quatrocentos que deveria convocar os cinco mil cidadãos. A seguir, Tucídides aponta os líderes deste movimento oligárquico. Pisandro, Antifonte, Frínicus e Teramênes.

Aristóteles apresenta na Athenaion Politeia (cap. 29) uma reunião na qual se propóe o estabelecimento dos Quatrocentos. Esta provavelmente é a reunião após o retorno de Pisandro. No entanto, as informações e o enfoque dado por Aristóteles giram em torno do desenvolvimento político e constitucional propostos. O filósofo cita o decreto de Pitódoros. Melóbios ${ }^{19}$ foi quem defendeu o decreto e Pitódoros seria o autor do mesmo. Nele se decidiu

18 Este é o momento em que Tucídides e a Athenaion Politeia discordam. A obra aristotélica apresenta um decreto que trata de trinta syngrapheis: os dez probouloi e mais vinte (ARISTÓTELES. Constituição dos Atenienses, 29).

19 Numerado como PA 10102 em Kirchner (1901). 
que além dos dez probouloi outros vinte com mais de 40 anos proporiam as novas leis. Cleitofon propôs uma emenda no decreto. Sugeriu que ao proporem leis levassem em consideração as patrious nomous ${ }^{20}$ estabelecidas por Clístenes quando este formulou a demokratia.

Melóbio é mencionado por diversas fontes como um dos membros dos Trinta Tiranos em 404. Ademais, aparece também como um defensor da proposta de Pitódoros ou como o proponente do decreto. Rhodes (1981, p. 370-372.) sugere que a fonte de Aristóteles não tenha sido diretamente a inscrição, mas sua citação no texto de outrem. Melóbios teria discursado a favor das modificações dos syngrapheis, mas por não fazer parte do conselho Pitódoros teria feito a moção para efetivar o decreto. Isto coincide com a proposta de Ostwald (1986, p. 369) de que a reunião teria sido preparada por Pisandro e Antifonte. Pisandro já falara a favor destas modificações na politeia e Antifonte era um orador conhecido por suas capacidades retóricas. Dois outros homens envolvidos com seu grupo, mas não diretamente reconhecidos como seus comparsas, poderiam propor algo similar e dar ares de ampla aceitação das propostas. Além de um futuro membro dos Trinta Tiranos Pitódoros foi o conselheiro a indicar o decreto, considerado um dos membros dos Trinta Tiranos por ter sido escolhido arconte durante seu governo.

Uma emenda foi proposta por Cleitofon. Seu pedido para atentar para as leis ancestrais de Clístenes como uma alternativa em relação ao que parecia estar sendo proposto pelos companheiros de Pisandro. Um retorno ao período de Sólon, com um conselho de quatrocentos, e com uma forte divisão censitária. Propondo um retorno a Clístenes, e associando este à constituição ancestral, Cleitofon propõe algo entre Sólon e a organização política de seu tempo, dominada pelo demos. Cleitofon é apontado por Aristófanes como um discípulo de Eurípides junto com Teramênes (Aristófanes. Rãs, 967). Platão dá seu nome a um de seus discursos e o apresenta também na República, onde aparece próximo a Trasímacus e Sócrates (PLATÃO, República, I.328b; PLATÃO, Clitofon 406a-410c). Em Athenaion Politeia, capítulo 34.3, Cleitofon figura entre os quatro colegas de Teramênes a tentar estabelecer a patrios politeia entre a paz com Esparta e o estabelecimento dos Trinta Tiranos em 404. Não há indícios suficientes para se apontar organizações polarizadas entre partidos exceto entre os beltistoi e dynatoi que trataram com Alcibíades. No entanto, parece haver desde este momento algumas divergências em como alcançar os objetivos de auxílio para efetivar o fim da guerra. 
Ao fim da apresentação do decreto Aristóteles comenta que a constituição de Clístenes não era demotiken ${ }^{21}$, popular, mas era próxima a de Sólon. Esta menção provavelmente serve para que os leitores do filósofo compreendam a escolha de se chamar Clístenes de guardião da democracia no texto do decreto. Sólon não é tratado como fundador da democracia, ou mesmo associado a ela de nenhuma forma, antes do século IV. Fuks (1971, p. 14-25) faz menção a estas diferentes representações de Sólon nos séculos V e IV. O autor aponta que Sólon não é mencionado em Heródoto em termos políticos e simplesmente nem aparece em Tucidides. Em Aristófanes aparece caracterizado como philodemos. Na comedia Demoi de Eupolis surge como um dos 4 atenienses dignos de serem tragos de volta da morte para ajudar nos problemas contemporâneos. No entanto, não há um papel especifico atribuído a ele nos fragmentos que sobrevieram da peça. Assim, a apresentação de Cleitofon (através de Aristóteles) seria a mais antiga menção de Sólon em relação a um programa político. A análise presente em Fuks, e muitas vezes mencionada por diversos outros autores, é expandida em uma pesquisa recente.

A trajetória dos testemunhos sobre Sólon entre os séculos $\mathrm{V}$ e IV apontam para uma inflexão de memória, em que o Sólon sábio e legislador são sobrepostos por uma temática atualizada e mais polêmica, a do Sólon democrata. Por que a elipse da memória de Sólon e o seu ressurgimento revigorado e reformulado mais de um século depois da sua morte? (...) Se para Heródoto Sólon está ligado aos Sete Sábios e ao mundo délfico, para a Athenaion Politeia Sólon está ligado à ideia de democracia moderada, e nada se comenta sobre outros sábios, o Oráculo de Delfos ou Creso da Lidia.

Em Plutarco (sec. I d. C.), na Vida de Sólon e no Banquete dos Sete Sábios (7, 152a), Sólon apresenta suas características de sábio harmonizadas com as de porta-voz da democracia. No sincretismo de memórias de Plutarco, que pouco em consideração leva a argumentação histórica mais acurada, o Sólon sábio e o Sólon democrata estão totalmente integrados (CORRÊA, 2012, p. 38-39).

O Sólon democrata então não figurava no imaginário dos atenienses do fim do século V. Hansen (1999) propóe que uma das características mais importantes das modificações políticas de Clístenes seria o decisivo aumento da participação dos demoi ${ }^{22}$ na organização política da polis. A visão de uma demokratia clisteniana como uma organização onde o poder está atrelado

21 Demotikos pode significar tanto "do povo" como "para o povo". Comum, popular, ou em prol do povo, populista.

22 Aqui usado como as vilas. 
aos demoi pode explicar sua associação com a democracia, ao invés desta ser associada ao Sábio, Poeta, Legislador, mas ainda não democrata, Sólon.

A aceitação de uma revisão das leis, feita por 30 syngrapheis constituídos a partir dos probouloi, provavelmente foi aceita como uma extensão da cautela expressa pela própria assembleia dois anos antes, quando do estabelecimento dos probouloi.

Nas passagens acerca do estabelecimento dos Quatrocentos muitas frases presentes na Athenaion Politeia são idênticas às de Tucídides, o que indica o uso do historiador como provável fonte para a obra aristotélica. Ainda assim algumas dificuldades surgem entre estes relatos. Tucídides aponta a formação dos Quatrocentos, que deveria convocar os Cinco Mil, mas nunca o fez, enquanto Aristóteles aponta a formação dos Cinco Mil, que indicaram cem anagrapheis, que então teriam formulado duas constituições. Estas constituições, uma para este governo novo, e outra para o futuro, presentes em Aristóteles, são muito debatidas entre pesquisadores e são chamadas de constituição para o presente e constituição para o futuro. A presença aparentemente inacabada das mesmas na Athenaion Politeia dificulta muito a associação com os eventos em Tucídides e mesmo com os eventos próprios à Athenaion Politeia. Independentemente da existência de uma ou duas propostas de constituição, ou da intenção dos redatores de que uma ou outra fosse posta em prática, ocorreu o estabelecimento de um conselho de quatrocentos, como atestado pelas inscrições e literatura do período. Aristóteles afirma que este número, quarenta de cada uma das dez tribos, é um retorno à tradição (ta patria) de Sólon, que instituíra um conselho com cem membros de cada uma das quatro tribos jônicas fundantes de Atenas. ${ }^{23}$

Os Quatrocentos eleitos e aceitos, ou pela massa geral de cidadãos (plethos, como quer Aristóteles) ou pela assembleia em Colonos onde poucos cidadãos estavam presentes (como o texto de Tucídides dá a entender), estabeleceram um governo sem a instituição dos Cinco Mil. Os Quatrocentos enviaram mensageiros aos Espartanos para negociar a paz e aos marinheiros em Samos para tentar convencê-los de que este governo dos Quatrocentos não era um malefício.

23 Para um alongado debate com indicações de outras obras e suas conclusões, ver Rhodes (1981, p. 362-404), onde o autor apresenta, acerca destas constituições, os trabalhos de WILAMOWITZ-MOELLENDORFF, 1893. i 103-5, ii. 357-8, apoiando a versão de Tucídides (História da Guerra do Peloponeso, VIII.69-70 e VIII.92-3) suportado por Lísias (Por Polístratos, 13; e Contra Nicômacos, 8). Busolt (1893, 3.ii.1483-4 ; 1920, i.73-4) propõe um erro por parte de Aristóteles; para reordenações cronológicas do texto de Aristóteles e de Tucídides, Beloch (1884), Lang (1967). 
Em Samos ${ }^{24}$, apesar de terem inicialmente aceitado um governo mais restrito como proposto por Pisandro, os Sâmios e os marinheiros foram persuadidos a repensar suas decisóes. Chaereas, retornando de Atenas, informou aos marinheiros sobre os horrores perpetrados pelos partidários de Pisandro e a instituição dos Quatrocentos. Léon, Diómedon, Trásilus e Trasíbulos já estavam em debate acerca de como se postar frente à possibilidade de que as propostas de Pisandro fossem levadas a cabo. Com o relato de Chaereas a persuasão dos marinheiros contra os Quatrocentos não deve ter sido difícil.

Chaereas era filho de Arquestratus. Arquestratus fora um associado de Efráltes, um dos generais a retomar Potidéia quando de sua defecção no início da Guerra do Peloponeso em 433/2. O Próprio Chaereas comandou forças terrestres em Cízicus, quando da vitória ateniense que restaurou a confiança na assembleia e levou ao fim do governo intermediário e ao retorno da organização da polis como antes dos Quatrocentos (ARISTÓTELES. Constituição dos Atenienses, 35.2; TUCÍDIDES, História da Guerra do Peloponeso, 1.57.6; IG I3 97.13, 322.36; M\&L 52.70; TUCÍDIDES, História da Guerra do Peloponeso, VIII.74.1, 86.3).

Trasíbulos sugeriu a reconvocação de Alcibíades para que este intervisse com Tissafernes. Note-se que uma das primeiras ações dos opositores dos Quatrocentos foi a convocação de Alcibíades, que incitou o movimento oligárquico.

O juramento efetivado pelos marinheiros em Samos é apresentado por Tucídides da seguinte forma:

(...) viver unidos sob uma forma de governo democrática, lutar na guerra contra os peloponésios até o fim e ser inimigos dos Quatrocentos e não se comunicar nem tentar a paz com eles

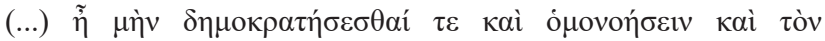

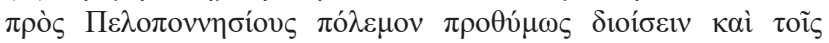

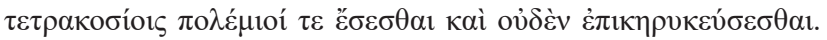
(TUCÍDIDES. História da Guerra do Peloponeso, VIII.75.2)

Apesar do uso do termo demokratésesthai por Tucídides o cerne do juramento recai sobre a oposição aos Quatrocentos e a manutenção da guerra. Um dos motivos para o desgosto dos atenienses em Samos, ainda de acordo com

24 O governo dos Quatrocentos é descrito na Athenaion Politeia nos capítulos 33 e 34, enquanto que em Tucídides há um relato nos capítulos VIII.73-97. 
Tucídides, foi o fato de que a patrios nomous fora abolida pelos Quatrocentos (TUCÍDIDES, História da Guerra do Peloponeso, VIII, 76.6).

Fuks (1971) propõe, em seu capitulo 2, que os termos patrioi nomoi, archaioi nomoi, politeiuesthai kata ta patria e patrios politeia seriam termos significando a mesma coisa entre os democratas. Além de significar a constituição atual, anterior à derrubada pelos Quatrocentos, seria uma forma de atacar os moderados. Seria uma forma de afirmar a patrios politeia com o período pós-Efiáltes, em oposição ao que os oligarcas propunham. Diferentes, então, dos moderados, que usavam patrios politeia como a democracia préEfiáltes, clisteniana.

Alcibíades então foi aclamado comandante do grupo em Samos, contrário aos Quatrocentos, mas não contrário aos Cinco Mil.

Teramênes e Aristócrates, membros dos Quatrocentos, começaram a incitar os oligarcas a estabelecerem os Cinco Mil de fato após receberem notícias desta revolta em Samos. Aristócrates foi o mais novo signatário da paz de Nícias. Serviu como taxiarca entre a expedição à Sicília e o governo dos Quatrocentos. Após a queda dos oligarcas serviu como general junto com Alcibíades. Após o exílio de Alcibíades e a troca de generais em 406 foi um dos poucos generais a permanecer no cargo e se juntar a outros mais inclinados a apoiar o demos. Foi um dos seis generais executados após a batalha de Arginusa. Certamente um oligarca se sua participação entre os Quatrocentos for levada em conta. Certamente apoiado pelo demos devido ao seu cargo de general após a queda dos oligarcas e mesmo após o exílio de Alcibíades e a destituição de Teramênes e Trasíbulos dos cargos de strategos quando de seus mandatos conjuntos. No entanto, executado por decisão da assembleia no famoso caso de impulsividade combatida por Sócrates dentro do corpo deliberativo do demos.

Frente a esta atribulação, os Quatrocentos decidiram por enviar uma embaixada aos espartanos a fim de alcançar a paz antes que os atenienses em Samos pudessem se mover contra seu poder. Nesta embaixada estavam Antifonte, Frínicus, Onômacles e Arqueptolemus ${ }^{25}$. Ademais, procuraram terminar a fortificação de Etionéia, o promontório na entrada do porto do Pireu, com a função dupla de proteção contra uma possível investida dos marinheiros e para acomodar enviados de esparta como aliados em caso de sucesso da embaixada. Os responsáveis por esta fortificação entre os Quatrocentos eram Aristarcus, Melatius e Aristóteles. Aristarcus parece ter defendido Frínicus no 
julgamento póstumo deste. Após a queda dos Quatrocentos foge de Atenas e trai um contingente ateniense na fronteira da Beócia. Condenado à morte em torno de 407/6 (IG II 2318.121-22; TUCÍDIDES, História da Guerra do Peloponeso, VIII, 90-98; XENOFONTE, Helênicas, I, 7.28). Nada se sabe sobre Melantius além de sua participação na fortificação de Etionéia. Aristóteles era um homem idoso que mais tarde se tornaria um dos Trinta Tiranos (XENOFONTE. Helênicas, II.3.2).

Esta divisão entre oligarcas mais a "perda" da frota em Samos para o governo tradicional em Atenas dificultou sobremaneira a manutenção do poder nas mãos dos Quatrocentos. Frínicus, um dos extremistas, foi assassinado. Seus assassinos receberiam, anos depois, uma estátua e seriam chamados de tiranicidas, tal qual os tiranicidas responsáveis pela morte do filho de Pisístratos. A ausência de Frínicus facilitou as intervenções de Teramênes a favor dos Cinco Mil.

Quatro meses após sua instituição, os Quatrocentos são depostos e em assembleia se afirma um governo intermediário controlado por (aproximadamente ${ }^{26}$ ) cinco mil homens capazes de manter suas próprias armas. Há de se notar que a assembleia que destituiu os Quatrocentos ocorreu na Pnix, local marcado pelas assembleias populares com a maioria do povo. A assembleia que instituiu os oligarcas se deu em Colonos, afastada da urbe ateniense. Sobre estas passagens Ste. Croix (1956) sugere que com a queda dos Quatrocentos uma proposta nova de Cinco Mil foi efetivada. Uma ekklesia democrática foi instaurada, mas apenas cinco mil hoplitas poderiam manter cargos. Sealey (1967) propóe que esta era a mesma proposta inicial dos Quatrocentos. Contra ambos Rhodes (1972) propóe que apesar de a proposta feita pelos Quatrocentos ser similar, após a queda dos oligarcas esta proposta implicava em cinco mil hoplitas com o status de cidadão, dentre os quais se retirariam os cargos. Ademais, além de tratar sobre a constituição dos Cinco Mil, Rhodes aponta os locais em Tucídides onde oligoi e demoi são colocados como um par antitético como no momento da deposição dos Quatrocentos. $\mathrm{O}$ autor aponta que:

Em outros locais Tucídides distingue as fações 'oligárquica' e 'democrática' como oligoi e demoi; (e.g. III.27.2 [Mitilene], III.72.2 ss. [Córcira], V.82.2 [Argos]). Normalmente é impossível definir onde a linha deveria ser traçada, mas nos locais onde oligoi são um grupo

26 O número exato dificilmente seria cinco mil, pois a quantidade de hoplitas (soldados de armas pesadas responsáveis pela manutenção de seu próprio equipamento) era maior. Um dos catalogueis, homens responsáveis por catalogar os nomes dos cinco mil, foi acusado mais tarde por sua relação com os Quatrocentos e em sua defesa aponta que arrolou nove mil nomes. 
pequeno e exclusivo demoi presumivelmente seria aplicado a todos os seus oponentes, inclusive homens de certa substância [posses]. (RHODES, 1972, p. 123 n. 65).

Esta diferenciação, ou a falta de precisão da mesma, é fundamental para se compreender a dificuldade entre helenistas em definir a derrubada do regime dos Quatrocentos como um retorno à democracia ou um jogo entre extremistas e moderados. Tanto a passagem dos Quatrocentos para os Cinco Mil quanto a dos Cinco Mil para o que alguns chamam de democracia restaurada envolvem descrições relativamente ambíguas por parte de Tucídides e Aristóteles. A derrubada dos Quatrocentos e o pedido para a instituição dos Cinco Mil por parte de seus opositores (sejam eles democratas ou apenas demoi como opositores dos oligoi) poderia significar um pedido para o estabelecimento de um governo moderado, mediano, ou o retorno à democracia. Esta é a interpretação de Tucídides acerca dos receios e dos verdadeiros motivos dos hoplitas que clamavam pelos Cinco Mil (TUCÍDIDES. História da Guerra do Peloponeso, VIII.92). Apesar de Ste Croix (1956, p. 9.) afirmar que havia um forte movimento de retorno à democracia, inclusive entre os hoplitas, Rhodes lembra que Tucídides escreve após o retorno à estrutura governamental anterior aos Quatrocentos, que ocorre em 410, e assim pode ter lido um desejo a este retorno entre todos os opositores dos oligarcas. Em diferentes momentos de Tucídides pode-se perceber uma acepção diversa de democracia entre diferentes grupos. Para os oligarcas até mesmo o regime dos Cinco Mil seria uma franca democracia (TUCÍDIDES. História da Guerra do Peloponeso, VIII, 92.2).

\section{Os Cinco Mil e os Entre Golpes}

É possível que a assembleia dos Cinco Mil fosse ampla a todos os cidadãos. Mesmo que esta interpretação das fontes seja a mais apropriada ainda houve a restrição do acesso a cargos públicos para não hoplitas; o fim do pagamento para cargos públicos, que não envolvidos com a guerra; o fim do pagamento por participação em assembleia e nas cortes. Estas práticas já impossibilitariam a participação de thetes e zeugitai pobres. Assim, a redução do corpo deliberativo e de oficiais presente no governo dos Quatrocentos é mantida. O problema com os Quatrocentos então, argumenta Rhodes ${ }^{27}$, não 
seria a limitação de poderes ou exclusão dos pagamentos, mas a manutenção indevida do poder e o desvio dos planos iniciais do processo que os levou ao poder $^{28}$

Dos generais que atuaram durante os Quatrocentos apenas Timócrates e Teramênes continuam nos cargos. Teramênes certamente devido ao seu envolvimento na derrubada dos Quatrocentos e instituição dos Cinco Mil, mesmo tendo feito parte dos Quatrocentos. Entre os oito novos generais estava Alcibíades, reconvocado a Atenas pelos Cinco Mil, acatando, portanto, a reconvocação proposta pelos marinheiros em Samos. Ademais Trasímaco e Trásilus também continuaram a atuar como generais. Desta feita Teramênes, identificado como líder dos moderados; Trasíbulos, identificado como o líder dos demotikoi, e Alcibíades; instigador do golpe dos Quatrocentos, atuaram como generais durante os Cinco Mil e depois durante o governo restaurado, até $407 / 6{ }^{29}$

Alguns dos membros dos Quatrocentos foram levados a júri e chegaram a ser executados. Onômacles, Antifonte e Arqueptolemus foram acusados e condenados. Onômacles fugiu, ficou exilado e retornou em 404 para se tornar um dos Trinta Tiranos. O processo contra estes oligarcas foi conduzido por Teramênes, Andron e Apolexis. Tanto Teramênes quanto Andron participaram dos Quatrocentos. Pouco se sabe de Apolexis, mas Andron, pai de Androtion, o autor de uma das Atthis, propôs o decreto que levou ao julgamento. Ele aparece em dois diálogos de platão, "Górgias" e "Protágoras", entre os membros do grupo de interessados em debates entre Sócrates e os sofistas.

Outro famoso caso de julgamento de um dos membros dos Quatrocentos é o de Frínicus. Crítias propôs um decreto para que o oligarca fosse julgado postumamente. Frínicus é condenado e seus restos mortais são jogados para fora da região da Ática. Os dois assassinos do oligarca são honrados como tiranicidas. Outro caso de ataque a membros dos Quatrocentos é o de Aristarcos e Aléxicles. Eles foram condenados à morte e tiveram seu enterro negado. Crítias não figura entre os Quatrocentos, no entanto se torna, em 404, o líder dos oligarcas extremistas dentro dos Trinta Tiranos. Ostwald sugere que sua oposição à Frínicus advém de sua proximidade com Alcibíades. (OSTWALD, 1986. pág. 402-3)

28 Hignet (1952) apresenta estas questóes de forma detalhada e pode servir de base para a comparação entre as fontes em Tucídides e em Aristóteles. Andrewes (1981) necessariamente deve acompanhar esta leitura, pois apesar do foco em Tucídides apresenta comparação com Aristóteles em seu excursus.

29 Ver TUCÍDIDES, História da Guerra do Peloponeso, VIII, 76-92; XENOFONTE. Helênicas, I, 1.22. 
Outra característica dos Cinco Mil que se assemelha às propostas dos Quatrocentos é a reconvocação dos exilados. Os Quatrocentos propuseram, mas não levaram a cabo. $\mathrm{O}$ governo intermediário efetuou a reconvocação. Muitos destes exilados são os condenados pela destruição das hermai e pela profanação dos mistérios de Elêusis. Muitos suspeitos de envolvimento com oligarcas e com uma preparação para um ataque ao demos na época.

A instituição dos anagrapheis, no entanto, pode ser vista como a mais influente das decisões do período. Este grupo aparece logo após o fim do governo intermediário e segue com sua função durante todo o período do governo restaurado. É interrompido durante os Trinta Tiranos e retorna com a democracia de 403, e permanece até 399. Não se sabe ao certo se foi iniciado no fim do governo intermediário ou no início do governo restaurado. Esta ação segue o exemplo dado pela instituição dos probouloi e, possivelmente, pelas ações dos oligarcas ao estabelecer syngrapheis. Com vinte homens somados aos dez probouloi, os syngrapheis ficam responsáveis pela revisão das leis ancestrais, inclusive das instituídas por Clístenes quando estabeleceu a democracia. ${ }^{30} \mathrm{Os}$ anagrapheis são estabelecidos com função similar. Com o intuito de revisar as leis de Sólon, e compilar estas leis válidas, sua tarefa associa as leis ancestrais com as leis de Sólon. Esta associação das revisões das leis ancestrais com as leis de Sólon logo após a queda dos Quatrocentos, influencia na invenção da tradição que trata do legislador como o pai da democracia, uma democracia baseada em leis inscritas. Com a interrupção, em 404, das atividades dos anagrapheis, por ordem dos Trinta Tiranos, a percepção de uma oposição entre oligarcas e a revisão e inscrição das "leis de Sólon" se intensifica. Sólon, o antitirano, e a inscrição de suas leis, se opõem a um grupo de oligarcas vistos como tiranos. A vitória da oposição da oligarquia, que se define por democracia, e sua relação com o caráter anti-tirânico (desde Clístenes e passando pela relação com o termo isonomia), levam a um Sólon fundador da democracia onde as leis estão inscritas para poderem ser revisadas.

Corrêa apresenta esta construção da imagem do antitirano como imagem propícia para o fundador da democracia:

Sólon utilizou tática retórica de "displacement" (IRWIN, 2008, p. 261) de forma a construir a unanimidade da sua rejeição à tirania, assim Sólon "é e não é um tirano" assim como Odisseu "é e não é um herói épico tradicional”. Antes de ser um democrata pela atribuição da tradição posterior, Sólon apresentou a si mesmo como um "antitirano", tal qual Odisseu é um "anti-herói" homérico. Através da sua poesia

30 Como apresentado no decreto de Pitódoros. 
Sólon controlou sua memória, e convenceu a tradição da sua recusa à tirania.

Se de fato Sólon foi ou não tirano de Atenas é uma questão que provavelmente se somará às perguntas sem respostas sobre a história da Atenas arcaica. $\mathrm{O}$ que se pode concluir é que a poesia atribuída a Sólon foi utilizada como uma intervenção na sua memória cultural, para afastar a imagem negativa de radicalidade e violência atribuída à tirania. Sólon foi eficiente em desvencilhar-se deste título negativo, e construiu sua imagem de legislador sábio e popular, mas não violento, nem radical e nem mesmo tirânico. Este "antitirano" foi construído a partir da sua obra poética, aliada à sua memória como sábio e legislador, e assim formou um corpo mais coeso e rico para a elaboração da base histórica para os princípios éticos e político que a Atbënaíon Politeía procura extrair da memória cultural de Sólon. O antitirano é mais compatível com a ideia de fundador da democracia do que o tirano pleno (CORRÊA, 2012, p. 85).

Sob o comando conjunto de Alcibíades, Teramênes e Trasíbulos, em 410 os atenienses tiveram uma série de vitórias, em Ábidos, Cinossema e Cízicus, o que levou ao estabelecimento de uma fortificação na Calcedônia. Estas vitórias colocam o controle do mar de Marmanara e dos estreitos de Dardanelos e do Bósforo sob controle ateniense. As taxas cobradas nestes locais aliviariam sobremaneira a polis (XENOFONTE. Helênicas, I.1. 4-7;11-23; DEMÓSTENES, Sobre Oraganização, 49-52;64; TUCÍDIDES, História da Guerra do Peloponeso, VIII, 104-6).

Esta situação econômica mais estável advinda de vitórias militares, sob o comando de três nomes de origens e influências políticas diversas, pode ter sido um ponto decisivo na passagem do governo intermediário para o governo restaurado. Certamente os ânimos eram esperançosos quando a assembleia negou um pedido de acordo de paz enviado pelos espartanos no mesmo ano. Incitados por Clêofon os atenienses recusaram a paz por acreditarem em uma situação melhor em futuro próximo, onde poderiam conseguir termos melhores. Clêofon parece ter sido o filho de um general, fabricante de liras, e que possivelmente estabeleceu a diobelia no período entre os Quatrocentos e os Trinta Tiranos. Quando, em 404, se opôs novamente aos termos espartanos para a paz foi rapidamente julgado por covardia durante batalha e condenado à morte. ${ }^{31}$

31 Não confundir com Cleitofon, proponente da emenda do decreto de Pitódoros. Ver ANDÓCIDES, Sobre os Mistérios, 146; ARISTÓTELES, Constituição dos Atenienses, 28.3; LÍSIAS. Sobre a Propriedade de Aristófanes, 28.3,48. 
Em 406, Lisandro derrotou os atenienses em Notium. Esta derrota parece ter ocorrido porque Alcibíades deixou um de seus oficiais encarregado da polis e este não seguiu suas ordens (XENOFONTE. Helênicas, I.5.11-15; P. Hellenica Oxyrhynchia IV; LÍSIAS. Contra Eratóstenes,71). Alcibíades foi considerado o responsável e, portanto, foi destituído do cargo de general e reconvocado para se apresentar à assembleia em Atenas. Os outros generais que o acompanhavam também foram destituídos do cargo, incluindo Trasíbulos. ${ }^{32}$ Alcibíades nunca retornou para Atenas. É possível que tenha receado uma punição severa devido a suas idas e vindas com o inimigo anos antes.

Oito dos dez generais atenienses foram destituídos neste momento. Possivelmente por suas relações com Alcibíades. Um grupo com associações muito mais firmes com a democracia foi estabelecido em seu lugar. Dois destes novos generais, Protomacus e Aristogenes, estão nomeados entre os que sobreviveram à tragédia de Arginusa. Conon e Aristócrates permaneceram no cargo. Aristócrates era o companheiro de Teramênes quando da derrubada dos Quatrocentos. Um dos oligarcas que parece ter mantido mais votos do que o líder dos moderados para o cargo de general. Diómedon e Léon, generais em Samos com Trasíbulos e Trásilus, são eleitos pela primeira vez desde 412 . Péricles, filho do grande general com a cortesã Aspásia, foi eleito junto com seu amigo Arquestratus. Erasinides, proponente do decreto que tornou os assassinos de Frínicus nos novos tiranicidas, também estava entre os novos generais. ${ }^{33}$

Menos de um ano depois todos os generais estiveram envolvidos na última grande vitória dos Atenienses na Guerra do Peloponeso, a batalha de Arginusa. Não cabe aqui apontar os detalhes da batalha, mas os resultados desta para o desenvolvimento político de Atenas. Em uma batalha para tomar Mitilene e resgatar Conon, um dos dez generais que era prisioneiro dos espartanos na polis em questão, mais de 120 navios peloponésios entraram em confronto com mais de 150 navios atenienses. O comandante espartano foi morto e mais de 60 navios peloponésios foram afundados. Os atenienses perderam apenas 12 navios e mais 13 foram avariados. No entanto, uma tempestade impediu a concretização do plano de tomar Mitilene, protegida por mais 50 navios peloponésios. Ademais os sobreviventes atenienses levados ao mar foram perdidos na tempestade sem ser resgatados pelos generais (XENOFONTE. Helênicas,I.6.34-38, I.7.4).

32 Teramênes saíra do cargo um ou dois anos antes e se tornou um trierarca.

33 XENOFONTE. Helênicas, I.5.11-15 para a lista dos generais. Ver Ostwald (1986. pág. 430, n.75.) para maiores informações acerca das fontes sobre os antecedentes destes generais. 
Em um momento de indignação a assembleia reconvocou oito dos generais e em um julgamento ilegal condenou todos à morte. Seis dos generais responderam à convocação e foram executados no dia seguinte ao julgamento. Arquestratus fora morto em Mitilene e Conon permaneceu na Polis. Os únicos generais sobreviventes foram Conon, Protomachus e Aristogenes.

Com a execução de seis generais dentre os mais ligados à democracia os atenienses passaram a ter novamente dificuldades em manter a estabilidade militar na batalha contra Esparta. Em alguns meses os espartanos estavam com sua marinha renovada com a ajuda dos persas e atacavam as bases atenienses, continuamente ganhando batalhas sobre os novos generais. Eventualmente Lisandro, comandando os espartanos, fez um cerco por mar e terra à Atenas.

Durante os meses de cerco a fome convenceu os atenienses a pedir os termos para se renderem. Estas negociações levariam ao estabelecimento dos Trinta Tiranos.

\section{Os Trinta e os Demotikoi}

Em 404, Atenas é finalmente cercada pelos espartanos e levada à capitulação. Um grupo de embaixadores liderados por Teramênes vai a Esparta para negociar os termos de rendição. Ao retornarem, a assembleia debate como proceder. Entre as definições apresentadas à assembleia está a necessidade de seguir a patrios politeia. Uma comissão de trinta pessoas é estabelecida para definir como organizar a polis a partir da patrios politeia, inclusive pela dificuldade em se definir o que é esta constituição ancestral. Este grupo de trinta toma o poder e, assim como os Quatrocentos, não efetiva a definição de um novo governo. Acabam por controlar a polis brutalmente como um governo de trinta oligarcas chamados, logo após os eventos, de Trinta Tiranos.

Acerca destes movimentos em Atenas há quatro fontes usualmente utilizadas. Athenaion Politeia, Diodorus Siculus, Xenofonte, nas Helênicas, e Justiniano. Destes apenas Xenofonte era contemporâneo dos eventos, e Athenaion Politeia éa mais específica em termos de modificações constitucionais. Apesar de serem levadas em consideração, e mencionadas quando apropriado, as obras de Diodorus Siculus e Justiniano não são as principais fontes utilizadas nesta pesquisa. Outros relatos de partes destes eventos são encontrados em Lísias e Andócides, bem como em algumas inscrições e a citação de outras inscrições que não sobreviveram até os dias atuais. ${ }^{34}$ 
Após uma devastadora derrota em Egospótamos ${ }^{35}$ os atenienses se viram obrigados a procurar os lacedemônios para se render, pois haviam perdido praticamente todos os barcos que ainda lhes restavam na guerra. Com poucos barcos e cercados por terra não tinham como importar grãos ou receber qualquer tipo de mantimento. Ademais, ficaram impossibilitados de responder militarmente a possíveis ataques. Teramênes e outros nove embaixadores foram enviados aos espartanos. Os termos apresentados aos atenienses variam entre os relatos. Todas as fontes concordam com a destruição da maioria dos navios e das muralhas da cidade, além da aceitação dos lacedemônios como aliados e a obrigação de seguir os lacedemônios por terra ou mar onde quer que fossem, guerreando a seu favor. A divergência gira em torno da chamada patrios politeia. Este ponto dos termos de rendição está presente em todos relatos, à exceção de Xenofonte.

Acerca da relação entre os movimentos políticos e militares e a procura pela patrios politeia três autores continuam centrais para o debate. Ostwald (1986) em seu capítulo sete, Finley (1971), em sua palestra inaugural e Fuks (1971). Estes autores propuseram que durante o período entre os dois golpes oligárquicos a constante falha da assembleia nas decisões sobre a guerra contra Esparta levou a um ambiente em que a procura por um passado mais sábio e justo permeava os debates políticos e as motivações para um fim da guerra. Este ambiente já estava se formando antes dos Quatrocentos e pode ser identificado especialmente através dos cargos dos probouloi e da peça Demoi, de Eupolis.

Apesar de breve momento de vitórias, com Alcibíades, Teramênes e Trasíbulos trabalhando juntos como generais, a sequência de falhas e decisões apressadas da assembleia levaram ao deslize de Atenas. Os mais experientes generais foram exilados ou destituídos do cargo por erros de outros. Os generais mais favoráveis ao demos foram executados logo após uma das maiores vitórias atenienses sobre os peloponésios. Por fim, a constante decisão de se levar a guerra até o fim para que acabasse logo, mas com a vitória ateniense, parece ter cegado o demos para as estratégias militares necessárias em uma longa guerra. O demos culpava a incompetência contemporânea, e a manipulação política dos mais abastados, pelos desastres na guerra. À procura de um modelo entre os antepassados para justificar suas ações investiam na procura pela patrios politeia, patrioi nomoi e outras patria. Mas estas constituiçóes ancestrais estavam presentem não somente nos discursos dos demotikoi (como

$35 \mathrm{Um}$ embate onde em torno de 180 navios de cada lado se digladiaram no mar. Poucas perdas por parte de Lisandro são registradas, mas apenas nove navios atenienses escaparam com Conon em comando (XENOFONTE, Helênicas, II, 1.17-22; DIODÓRO SÍCULO, Biblioteca Histórica, XIII, 104.8-106.8). 
Lísias e Aristóteles chamam os opositores dos oligarcas), mas também entre os oligarcas, sejam eles extremistas ou moderados. Usavam estes termos para justificar suas propostas perante o demos ou para melhor tratar de guiar as modificações políticas intentadas pelos grupos.

Esta visão de três grupos organizados, ou ao menos identificados como tais, vem desde os atenienses antigos. Alguns até contemporâneos aos eventos.

Com a paz, tendo sido concluída a partir de termos para conduzir o governo de acordo com a constituição ancestral, o grupo popular se esforçava para preservar o demos, mas os notáveis que pertenciam às betaireiai e aqueles exilados que retornaram após a paz, estavam ansiosos por uma oligarquia, enquanto aqueles notáveis que não eram membros das hetaireiai, mas doutra feita, não eram inferiores em reputação a nenhum cidadão, procuravam a constituição ancestral; os membros deste grupo eram Arquinos, Anitus, Cleitofon e Formisius, enquanto seu principal líder era Teramênes. E quando Lisandro tomou o lado dos oligarcas o demos se sentiu compelido e forçado a votar pela oligarquia.

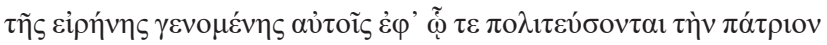

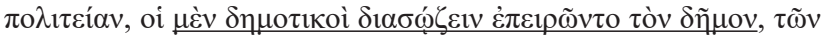

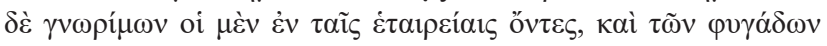

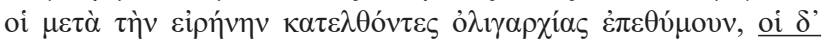

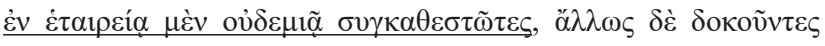

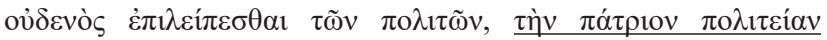

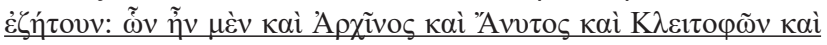

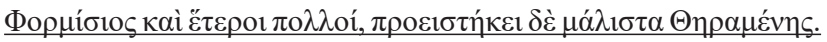

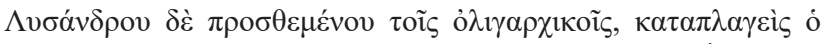

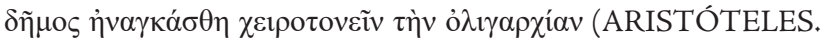
Constituição dos Atenienses, 34.3) $)^{36}$

No entanto, Dionísio de Halicarnasso e alguns outros autores posteriores tendem a identificar apenas dois grupos distintos nestes embates políticos, juntando os Teramistas com os democratas.

Pois aqueles interessados em uma oligarquia afirmaram que a antiga forma de governar deveria ser restituída. Nesta, somente poucos ficavam a frente do todo. Enquanto a massa desejosa da democracia propôs a constituição de seus pais e afirmaram que esta era acordada como sendo democracia. 


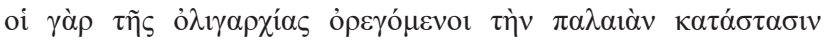

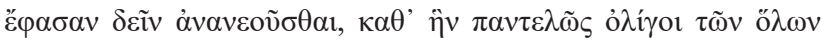

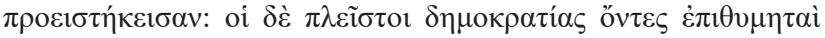

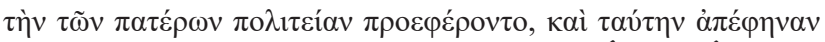

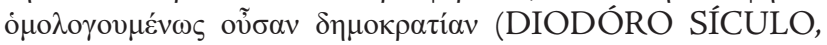
Biblioteca Histórica, XIV.3). ${ }^{37}$

Assim, Teramênes aparece como defensor das propostas da massa, em oposição àqueles interessados na oligarquia.

Desde a descoberta da Athenaion Politeia tem se preferido descartar as descrições destas fontes, por serem muito posteriores em relação às anteriormente mencionadas e pela corroboração entre Tucídides, Xenofonte e a obra aristotélica. Apesar da escolha deste trabalho em procurar sempre por fontes mais próximas aos eventos, estas relações merecem reflexão a partir de uma explicação de processo de aglutinação entre os grupos. Talvez esta representação em Diodorus, e outros posteriores a ele, seja um reflexo do desenvolvimento dos próprios eventos. Parece que os moderados se aliaram aos demotikoi e ajudaram a estruturar seu movimento contra os extremistas. $\mathrm{O}$ que se debatia entre todos era o futuro de Atenas. Todos procuravam resolver a questão da guerra. Para sair de uma situação tensa procuravam uma Atenas futura mais parecida com a administrada pelos sábios antigos de sua história. Cada um olhando para um momento no passado que lhes justificassem as propostas para o futuro.

Fuks (1971) sugere que a proposta de uma patrios politeia é originalmente dos Teramistas, os moderados. No entanto, Tucídides aponta os marinheiros em Samos falando já de uma patrios politeia, apesar de parecerem se referir ao governo recém derrubado pelos Quatrocentos. A Athenaion Politeia apresenta tanto extremistas quanto moderados compondo o decreto de Pitódoros, que procura as patrioi nomoi de Clístenes. Trasímaco reflete brevemente sobre esta procura tripla, em um de seus poucos fragmentos que sobreviveram até hoje. ${ }^{38}$

Eu queria, atenienses, ter pertencido àquele tempo antigo onde o silencia bastava aos jovens, pois o estado das coisas não os forçava a fazer discursos; e os homens mais velhos estavam administrando a cidade devidamente. (...) Eu começarei mostrando que ao falar contra um ao outro, aqueles dentre nossos oradores, e outros também,

37 Tradução a partir do texto estabelecido em DIODORUS et al.,1888.

38 Trasímacos foi um sofista nascido na Calcedônia, no Bósforo. Passou boa parte de sua vida em Atenas e figura na República e no Fedro de Platão, onde aparece como uma figura que trata de desenvolver a teoria retórica. Tradução do Italiano presente na obra de DIELS-KRANZ número 85 fragmento B1. 
que estão em conflito entre si, passaram pelo que inevitavelmente acontece com pessoas que tentam ganhar sem pensar. Eles acham que estão dizendo o oposto um ao outro e falham em se aperceber que estão procurando as mesmas políticas. E que os argumentos de seus oponentes estão incluídos nos seus. Apenas considerem, desde o início, o que cada um deles está procurando. A princípio, nossa constituição ancestral os preocupa, apesar de ser bem fácil de compreender e ser o que todos os cidadãos têm em comum.

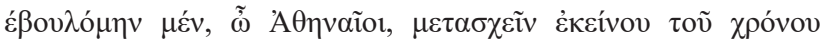

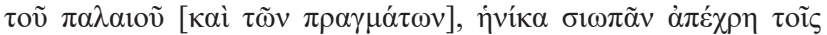

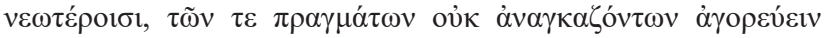

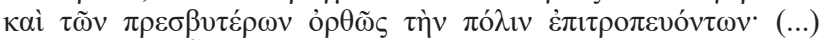

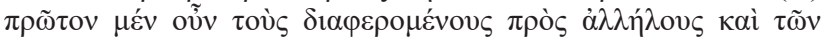

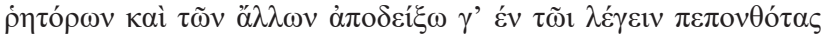

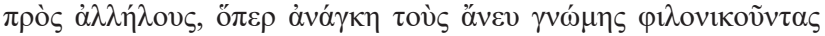

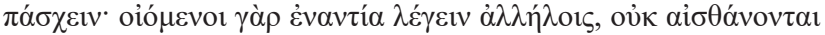

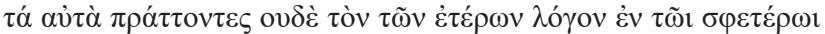

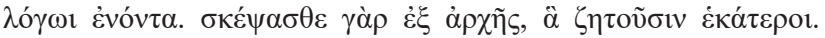

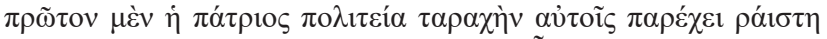

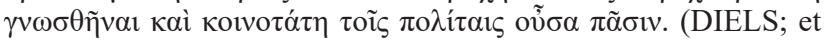
al. 2006)

Fuks (1971) apresenta a teoria de que os termos kata ta patria, ta patrione patrios politeia eram utilizados durante o século $\mathrm{V}$ frequentemente em acordos bilaterais ao definirem as condições de autonomia das poleis em questão. ${ }^{39}$ $\mathrm{O}$ uso feito pelos atenienses da patrios politeia em debates internos parece ecoar estas práticas e expandir para o passado de Atenas as possibilidades de se tomar os termos como definições de politeiai específicas. A exemplo disto, parece significar para os demotikoi, uma autoafirmação de autonomia política.

Hamilton (1970), no entanto, propõe que as ações de Lisandro nos anos anteriores indicam uma preferência em delimitar uma oligarquia limitada iniciada pela escolha de dez homens para representar seu interesse na polis. Quando do uso do termo patrios politeia como parte da rendição de Atenas, as práticas recentes de Lisandro poderiam ser o que o informou. No entanto, os debates internos em Atenas já faziam uso destes termos para significar coisas diferentes. Com Lisandro entregando seu apoio aos oligarcas, um meio termo alcançado foi o estabelecimento de um grupo de dez homens de cada uma das organizações percebidas na época. ${ }^{40}$

\footnotetext{
39 Ver indícios apresentados por Fuks (1971), especialmente nas páginas 59-61 e notas 16-17.
}

40 Divergências nas fontes sugerem a existência de dois grupos de trinta homens. Primeiro, representando as facçóes, mas após intervenção de Lisandro apenas trinta oligarcas. Há ainda a possibilidade de que apenas um grupo de trinta tenha sido estabelecido, ou com representatividade ou apenas composto por oligarcas. Esta última possibilidade é a que melhor corresponde com a maioria das fontes. 
Após a queda dos Quatrocentos muitos de seus integrantes fugiram de Atenas, como Onômacles, que apesar de condenado à morte junto com Arquestratus e Antifonte escapou da polis antes de sua execução. Parte do acordo com Lisandro envolvia o retorno dos exilados. Assim, muitos dos quatrocentos oligarcas retornaram, alguns chegando a participar dos Trinta Tiranos.

Sobre os Trinta Tiranos sabe-se alguma coisa sobre onze deles. Os outros membros são apenas nomes em uma lista, devido à falta de menções acerca de suas pessoas nas fontes de que se dispóe. Xenofonte Lista os seguintes trinta nomes para os Trinta Tiranos: Aristóteles, Cáricles, Crítias, Dracontide, Eratóstenes, Melóbius, Mnasílocus, Onômacles, Sófocles (não o tragediógrafo), Teógnis, Teramênes; entre os que se tem alguma informação; Anétius, Aresias, Cleomedes, Caereleos, Cremon, Diocles, Erasistratus, Ésquines, Euclídes, Eumates, Fédrias, Feido, Hiero, Hipolocus, Hipomacus, Mnesiteides, Peison, Polícares, Teogenes; entre os que não se pode inferir nada (XENOFONTE. Helênicas, II, 3.2).

Aristóteles, um pupilo de Zenon, fora um general em 431/0 e fez parte dos Quatrocentos. Foi um dos responsáveis pela fortificação de Etionéia e após fugir de Atenas, quando da queda dos Quatrocentos, refugiou-se em Esparta, chegando a atuar como representante de Lisandro no debate sobre a rendição de Atenas em Esparta (IG I³ 366.6; XENOFONTE. Helênicas, II.2.17-18).

Melóbius foi um dos defensores do decreto de Pitódoros, que estabeleceu os trinta syngrapheis que estipularam os Quatrocentos, em 411. Pitódoros não esteve entre os Trinta Tiranos, mas foi escolhido por eles como arconte epônimo. No entanto, ele não é considerado arconte nas listas atenienses posteriores. $\mathrm{O}$ ano de 404 é considerado anarchos, sem arconte (ARISTÓTELES, Constituição dos Atenienses, 29.1; LÍSIAS, Contra Eratóstenes, 12-20). Mnasílocus foi arconte epônimo durante os Quatrocentos e nada se sabe dele até aparecer entre os Trinta Tiranos. Provavelmente esteve em exílio durante todo este período (ARISTÓTELES, Constituição dos Atenienses, 33.1). Onômacles, como já foi notado, esteve entre os Generais em Samos quando da primeira investida de Alcibíades em instigar uma mudança de governo para uma forma mais oligárquica. Ademais, foi um dos Quatrocentos e um dos enviados para negociar com Esparta. Por esta última ação foi condenado à morte, mas fugiu de Atenas e retornou como um dos Trinta Tiranos. ${ }^{41}$

Cáricles é uma figura que não parece representar um grupo político específico. Em 415 foi um dos investigadores do caso das hermai, junto com 


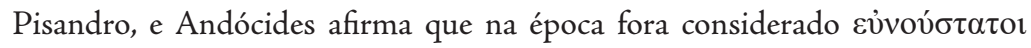
$\tau \tilde{\varphi} \delta \eta \dot{\mu} \mu$, amigável ao demos. Em 414, lutou contra os peloponésios como um strategos. Isócrates menciona que ele passou alguns anos em exílio e ao retornar maltratou a cidade (ANDÓCIDES, Sobre os Mistérios, 36; TUCÍDIDES, História da Guerra do Peloponeso, VII.20,26; DIODÓRO SÍCULO, Biblioteca Histórica, XIII.9.2; ISÓCRATES, Sobre o Tronco de Cavalos, 42). Cáricles e Crítias são apontados como os líderes dos oligarcas extremistas. Esta menção ocorre em fontes de diferentes influências e que tiveram suas informaçôes a partir de diferentes fontes (ANDÓCIDES, Sobre os Mistérios, 101; ARISTÓTELES, Política, 5.6, I.305b.26; LÍSIAS, Contra Eratóstenes, 55; XENOFONTE, Helênicas, II, 3.2).

Crítias é um dos mais bem conhecidos destes nomes devido a seu envolvimento com Sócrates e os sofistas e tanto pelos textos de Platão como seus próprios. ${ }^{42}$ Crítias aparece como um interlocutor de Sócrates e interessado em Górgias nos diálogos “Cármides”,"Timeu” e "Crítias”. Xenofonte sugere que Crítias e Alcibíades tenham se afastado de Sócrates por terem procurado um espaço na vida pública (XENOFONTE. Memoráveis, I, 2.12-16;24-39). Sua primeira aparição pública foi a proposta do decreto que levou Frínicus a ser exumado, julgado e condenado a ter seus restos mortais extraídos do território ático e seus descendentes proibidos de adentrar na Ática. O primo de Crítias, Cármides, se tornou um dos Dez do Pireu. ${ }^{43}$

Sófocles parece ter sido um strategos em 426/5 e 425/4 e foi exilado como resultado de sua euthyna por não ter conseguido subjugar a Sicília. ${ }^{44}$ Dracontides foi o proponente do decreto que instituiu os Trinta Tiranos e é, possivelmente, um dos personagens de Aristófanes (Vespas) e de Platão Comicus (Sofistas), respresentado como um participante em diversos processos. ${ }^{45}$ Teógnis pode ser associado ao poeta trágico satirizado por Aristófanes nas "Arcarnéia" e "Thesmophoriazousae". Lísias apresenta Teógnis incitando os Trinta Tiranos a excluir os metecos e tomar as posses destes.

42 Sobreviveram fragmentos de textos sobre a constituição dos lacedemônios, constituição da Tessália, poesias, fragmentos de uma tragédia e de uma prosa acerca da vida de alguns atenienses como Arquílocus, Temístocles e Cimon. Ver Diels-Kranz 88.

43 Grupo de dez arcontes escolhidos pelos Trinta Tiranos especificamente para cuidar do Pireu.

44 Develin (1989), TUCÍDIDES, História da Guerra do Peloponeso, IV.65.3. Não confundir com o tragediógrafo, que também foi strategos em 441/0 e 423/22 e foi proboulos de 413 a 411 e, possivelmente, um dos trinta syngrapheis que instituíram os Quatrocentos.

45 ARISTÓTELES. Constituição dos Atenienses, 34.3; LÍSIAS. Contra Eratóstenes, 73; Ostwald (1986. pág. 466.) sugere que isto seria um indício de que Dracontides tenha sido um pupilo de um sofista. 
Ademais, foi um dos homens que procurou pegar Lísias quando este fugiu das mãos dos Trinta Tiranos após terem capturado seu irmão (LÍSIAS. Contra Eratóstenes, 6.2; 13-15). Outro membro dos Trinta envolvido com Lísias foi Eratóstenes. $\mathrm{O}$ único discurso de Lísias apresentado por ele mesmo foi contra Eratóstenes pelo assassinato de seu irmão, de acordo com o caso mencionado acima. Eratóstenes foi um trierarca estacionado em Samos em 411/10 e, possivelmente, esteve entre os dynatotatoi em assembleia oligárquica (DEVELIN, 1989).

Teramênes é citado por Aristóteles como o líder dos moderados junto com Arquinos, Anitus, Cleitofon e Formisius. Nenhum destes colegas de Teramênes figura entre os Trinta Tiranos. Cleitofon propôs a emenda ao decreto de Pitódoros pedindo que se investigasse a constituição de Clístenes. Membro do círculo de Sócrates e figurando nos diálogos de Platão, parece ser um representante do grupo de intelectuais moderados. Anitus foi um dos acusadores de Sócrates em 399. Ele é apresentado por Platão e Xenofonte como um homem de posses ${ }^{46}$ que desprezava os sofistas. Anitus foi um general em 409 em Pilos, e julgado por traição após uma perda. Aristóteles afirma que teria sido o primeiro ateniense a conseguir ser absolvido através de suborno (ARISTÓTELES, Constituição dos Atenienses, 29.5, 34.3). Quando Trasíbulos atacou os Trinta Tiranos, a partir de Phyle, Anitus esteve junto ao grupo de opositores aos oligarcas. Isócrates, Xenofonte e Platão dizem que Anitus foi importante no reestabelecimento da democracia em Atenas (XENOFONTE, Helênicas, II.3.42-4; LÍSIAS, Contra Agóratos,78, 82). Formisius aparece apenas após a queda dos Trinta Tiranos propondo o retorno dos exilados pelos Trinta, mas com cidadania apenas para os que tivessem terras na Ática. Contra Nicômacos, de Lísias, é um discurso contra esta proposta. Arquinos também esteve envolvido com propostas relacionadas aos exilados. Trasíbulos propôs o retorno dos exilados e cidadania a todos, inclusive metecos, como Lísias. Aquinus, seu companheiro em Phyle e no Pireu, encabeçou uma graphe paranomon contra este decreto e fez sua própria proposta de cidadania, aprovada pela polis. Arquinus é visto como moderado em suas ações e ajuda na reconciliação e restauração da democracia, não apenas nestas ações, mas também nas palavras de Aristóteles e em seus ecos em Demóstenes (ARISTÓTELES, Constituição dos Atenienses, 40.1-2; DEMÓSTENES, Contra Timócrates, 135).

A instituição dos Trinta foi dada em assembleia com o intuito de estabelecer trinta syngrapheis, como no evento dos Quatrocentos. No entanto,

46 Teria herdado um curtume de seu pai. 
a pressão de Lisandro impediu que a escolha dos trinta fosse de livre escolha da assembleia, mas as fontes concordam que a assembleia votou na escolha destes Trinta. Tanto Lísias quanto Aristóteles (Constituição dos Atenienses, 35.2) sugerem que a intenção inicial dos Trinta era vista com bons olhos, pois intentavam "livrar a cidade de homens injustos e guiar os outros cidadãos à justiça” (LÍSIAS, Contra Eratóstenes, 5).

Os Trinta estabeleceram: um conselho de quinhentos bouleutai; nove arcontes; os Onze, tradicionalmente escolhidos para funcionarem como policiamento; strategoi; e tesoureiros do tesouro de Atena e dos outros deuses. Um grupo incomum estabelecido pelos Trinta Tiranos foram os Dez. Grupo responsável por todos os aspectos do Pireu e que respondiam apenas aos Trinta Tiranos.

Os Trinta Tiranos presidiram a Boule em alguns julgamentos de homens considerados sicofantas. Muitos destes homens foram condenados à morte. No entanto, isto foi bem recebido pelos atenienses que viam os sicofantas como aproveitadores que atrapalhavam o processo legal ateniense. Os Trinta passaram a confiscar os bens destes homens (XENOFONTE, Helênicas, II.3.12; ARISTÓTELES, Constituição dos Atenienses, 35.3; DIODÓRO SÍCULO, Biblioteca Histórica, XIV.4.2; LÍSIAS, Contra uma Acusação de Subversão da Democracia, 19).

Apesar destas modificações e do estabelecimento de alguns cargos nenhuma lei nova foi feita, mas leis de Efráltes foram canceladas. Neste ponto extremistas e moderados parecem concordar. Outras leis passaram a ser destruídas, como por exemplo algumas das inscriçóes iniciadas pelos anagrapheis e que foram rasuradas no período dos Trinta Tiranos. ${ }^{47}$

Dentre os Trinta ainda havia um grupo apoiando Teramênes que pedia pelo estabelecimento dos Cinco Mil. Uma lista de três mil foi estabelecida pelos Trinta Tiranos. A seguir, os oligarcas decidem continuar com os julgamentos, mas desta vez tendo os metecos como alvo. Muitos metecos desaprovavam as decisões dos Trinta Tiranos. Para combater estes opositores os oligarcas iniciaram uma série de julgamentos seguidos de execuções e tomada das posses dos executados. Teramênes se pronuncia contrário a estas ações e em seguida é excluído dos Trinta, dos três mil e julgado e executado pelos Trinta Tiranos. Neste período muitos fugiram de Atenas ou foram exilados. Lísias foi um dos metecos que fugiram para evitar de serem mortos, como o irmão de Lísias. Trasíbulos foi um dos exilados também e junto com outros atenienses na mesma situação formou uma iniciativa contra os Trinta Tiranos em Phyle.

47 ARISTÓTELES. Constituição dos Atenienses, 35.2; ver Dow (1961) e Fingarette (1971) e IG I' 236-41. 
Frente a estas oposições os Trinta recolhem as armas daqueles que não fazem parte dos três mil e as depositam na acrópole. Algum tempo depois apenas os três mil têm permissão para residir na asty. ${ }^{48}$ Os julgamentos continuaram e não mais se restringiam aos metecos. As fontes concordam com a morte de 1500 atenienses sob o comando dos Trinta Tiranos.

Trasíbulos estava com quase mil homens em Phyle quando os Trinta Tiranos ofereceram a Trasíbulos o lugar de Teramênes entre os Trinta. Com sua recusa os oligarcas atacam Phyle. Entre a tática de Trasíbulos e uma tempestade de neve os oligarcas perdem a batalha e retornam para Atenas.

Trasíbulos e Arquinos, com o auxílio de alguns metecos como Lísias, marcham contra o Pireu e tomam o porto. Os oligarcas atacam novamente e perdem uma segunda vez. Neste combate Crítias e Hipomacus morrem. Esta situação causa temor entre os Trinta Tiranos e alguns membros dos três mil exigem mudanças. Dez homens são selecionados para substituir os Trinta Tiranos e os remanescentes dos Trinta fogem para Elêusis.

Os Dez tentam atacar o Pireu e falham novamente. Assim, enviam um pedido de auxílio aos espartanos. Pausânias vai pessoalmente a Atenas e intercede auxiliando em uma reconciliação. Meletus e Cefísofon, dentre os oligarcas, se apresentaram como representantes dos oligarcas na reunião com Pausânias.

Uma reconciliação que previa o estabelecimento de uma polis independente de Atenas como refúgio para os oligarcas e uma cláusula de não lembrar erros e ações passadas poderia ter sido o fim das animosidades entre oligarcas e seus opositores, não mais vistos como moderados e demotikoi, mas como um grupo só. O conflito girava agora entre "os da asty" e "os do Pireu" (ARISTÓTELES, Constituição dos Atenienses, 39.6; XENOFONTE, Helênicas, II.4). Pouco tempo depois os atenienses recebem notícias de que os oligarcas em Elêusis estavam contatando mercenários. Elêusis é invadida e os oligarcas são finalmente postos abaixo.

Para definir o que deveria acontecer, e como restaurar o governo, uma assembleia escolheu uma comissão de vinte homens para governar a cidade enquanto se decidisse o que fazer com a constituição e até se restaurar as cortes e reiniciar as revisões das leis de Sólon iniciadas pelos anagrapheis após a queda dos Quatrocentos. Após a queda dos Trinta seus opositores decidem eleger uma comissão de vinte, com os mesmos objetivos iniciais dos Trinta Tiranos: revisar as leis e estabelecer uma nova constituição. Cefísofon foi escolhido como

48 Urbe, centro urbano da polis atenienses, em torno da acrópolis. 
secretário da Boule e durante seu mandato foi passado o decreto de cidadania para os Sâmios, com uma emenda do próprio Cefísofon com honrarias adicionais. Arquinos e Anitus propuseram decretos relacionados à cidadania e à honrarias para os heróis de Phyle. Arquinos também foi o responsável pelo decreto que estabeleceu o dialeto jônico como dialeto oficial de Atenas em suas inscrições públicas. Este decreto é um entre uma série de definições legais que são iniciadas sob o arcontado de Euclídes em 403, quando da definição de que forma de politeia os atenienses queriam ter. Agora sem uma guerra a travar, sem um possível aliado a apaziguar, os atenienses puderam estabelecer sua patrios politeia como seria relembrada por Aristóteles em sua "Política":

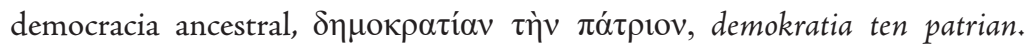
(ARISTÓTELES, Política, II, 1273b.38). ${ }^{49}$

Esta ideia de uma constituição ancestral que se percebe uma democracia ancestral vem a partir da vitória dos opositores dos oligarcas. Antes de uma disputa por ideologias políticas se percebe uma disputa pela forma de se alcançar o fim da guerra, ou a vitória mais rápida. Entre as propostas a polarização se dá entre influentes e homens de bem, dynatotatoi e beltistoi e o povo, a massa, demos, plethos. Neste embate que se descobrem os extremistas, os moderados Teramistas e os demotikoi. Mas para além da formação destes demotikoi está a forma de pensar a oposição aos oligarcas como a democracia. Estes oligarcas, tão caracterizados como tiranos, que interrompem as revisões das leis de Sólon. Este é o início da tradição da democracia ancestral. Da democracia de Sólon, das leis de Sólon, das leis inscritas de Sólon.

Mossé, se apercebendo deste processo, refletiu sobre como este se deu. "Eu gostaria, de minha parte, de tentar mostrar como se elaborou, a partir do fim do século V, a imagem de um Sólon, fundador da democracia ateniense." (MOSSÉ, 1979).

Tanto Mossé quanto Rhodes (1993, p. 260) apontam para uma situação onde os atenienses, e até mesmo os demotikoi do século V, viam Clístenes como o fundador da democracia, ou ao menos da forma de governo que os oligarcas queriam derrubar. Com as propagandas dos programas políticos, no fim do século, a disputa pela ancestralidade da politeia levou a uma idealização da constituição, da democracia advinda de Sólon. Após a derrubada dos Trinta Tiranos, homens como Arquinos e Anitus se opunham a qualquer medida revolucionária. A oposição ao decreto de Trasíbulos, que propunha entregar a cidadania para todos os metecos envolvidos na batalha em Phyle, não é puramente para evitar honraria aos heróis da derrubada dos Trinta Tiranos.

49 Presente no texto estabelecido por ROSS, 1957. 
Este vem junto com um novo decreto, acatado pela assembleia, que propóe honrarias aos heróis de Phyle, mas mantendo a cidadania apenas para os atenienses. Esta relação de equilíbrio entre dois extremos cai sob a égide de Sólon. Igual espaço para os dois lados, mas sem deixar um ganhar sobre o outro. A anistia estabelecida caminha no mesmo sentido. Duas outras questões corroboram com a constituição da tradição em torno de Sólon. A revisão das leis em vigência que ocorreram de 410 até 399, era chamada de revisão das leis de Sólon. A imagem de um Sólon como antitirano ${ }^{50}$ rapidamente se acoplou à oposição entre os oligarcas extremistas e seus opositores, que os denominaram tiranos.

Este processo, então, se encontra na confluência dos eventos de 411, de 404, e o processo dos anagrapheis, ou nomothetai como quer Tucídides, que perpassa estes eventos.

De acordo com Tucídides, o governo pós Quatrocentos decidiu efetivar uma revisão das leis por nomothetai. O cargo dos nomothetai e o processo de nomothesia são atestados apenas após 403 , quando da definição da diferença entre lei e decreto. Em Tucídides se tem a primeira utilização do termo para um cargo de revisão de leis. Ostwald (1986, p. 405-7.) propóe que o termo usado por Tucídides não seria o título, mas um termo descritivo para uma comissão de anagrapheis ou syngrapheis. $\mathrm{Na}$ reinscrição da lei de Drakon ${ }^{51}$ um grupo de anagrapheis ton nomon (anagrafeis das leis) era responsável pela aquisição da lei com o arconte basileus e pela publicação da mesma. Em Lísias XXX (Contra Nicômacos), Nicômacos é acusado pelo cliente de Lísias por mudar e adicionar leis quando sua função seria apenas compilar. Os dois períodos dados por Lísias para o cargo de Nicômacos são 6 anos e 4 anos, provavelmente incluindo os anos de 410 a 404 e 403 a 399, datas que corroboram com a teoria de que os anagrapheis teriam sido estabelecidos após os Quatrocentos e se mantiveram no cargo até 399, com um interstício durante o período dos Trinta Tiranos.

Muito se debateu acerca das funções destes anagrapheis. Lísias afirma que sua função, ao menos no primeiro mandato, seria inscrever as leis de Sólon. Como pode se verificar já em Andócides (I, 95-6), o uso da expressão "leis de Sólon" pode ser ligado a leis produzidas muito posteriormente ao antigo legislador. ${ }^{52}$ Isto se torna cada vez mais comum no século IV, quando

50 Ver Corrêa (2012)

51 IG I$^{2} 115$ + IG I3 104. =Fornara 15. = Stroud (1984). = M\&L 86.

52 Neste caso em específico Andócides se refere a um decreto de 409. 
Demóstenes chega a apontar leis de homicídio, contemporâneas, como leis de Drakon, seguindo o mesmo tipo de tradição onde a expressão significa leis válidas no momento; ou leis inscritas; ou ainda, no caso de Drakon, qualquer lei acerca de homicídio. ${ }^{53}$ Rhodes (1991) parece acertar quando propóe que:

No seu primeiro mandato, então, eu acredito que os anagrapheis, homens com status de secretários, foram originalmente ordenados a republicar as leis de Sólon. E foi, eventualmente, decidido que isto significava que eles deveriam encontrar e republicar todas as leis escritas válidas que se aplicassem a toda a comunidade dos cidadãos atenienses.

Robertson (1990) propôs que a produção desta revisão teria o objetivo de publicar não todas as leis, mas as relevantes, para serem colocadas no novo arquivo central. A construção do novo Bouleuterion, datada entre 409 e 405 , é proposta por Sickinger (1999; 1999) e Boegehold (1972) como o mesmo período em que o chamado velho Bouleuterion teria passado a servir como o arquivo central. Anos depois este "velho Bouleuterion" viria a ser conhecido como Metroon em homenagem ao santuário da mãe dos deuses.

Estas mudanças e revisões culminam no ano de Euclides, 403/2. Além da revisão das leis de Sólon, definições importantes são votadas logo após a derrubada dos Trinta Tiranos. Estas são claramente apresentadas em Andócides e facilmente verificadas nas epigrafias do período. Neste ano se define 1 - a diferença entre leis e decretos, entre nomoi e psephismata. 2- O dialeto jônico é estabelecido como o dialeto oficial em Atenas para a publicação das leis. 3 - Leis não escritas são proibidas. Por fim, cabe apontar uma inscrição chamada de decreto de Theozotides (STROUD, 1971).${ }^{54}$ Este decreto é datado de 403/2 e trata da compensação em dinheiro para os órfãos dos homens que lutaram pela democracia contra a oligarquia. Esta é a primeira inscrição na qual a palavra demokratia é atestada sem a necessidade de reconstrução. Esta é também a primeira vez em que a palavra oligarchia aparece em uma inscrição. ${ }^{55}$ A falta do termo oligarchia não deve ser lida como a inexistência do termo antes deste período. A literatura de períodos anteriores atesta fortemente

53 Acerca dos debates sobre os anagrapheis ver também: Sealey (1975), Hignett (1952), Harrison (1955;1961), Rhodes (1991), Dow (1953;1961;1963), Lang (1967), Gallia (2004), De Romilly (1990), Carawan (2002;2006), Noel (1990) e Joyce (2008).

54 Stroud apresenta a editio princeps, primeira edição de uma inscrição. A mesma aparece em SEG 28.46, (WOODHEAD, 1997. 106A.), Harding, P. (1985). From the End of the Peloponnesian War to the Battle of Ipsus, Cambridge University Press. № 8.

55 Neste caso está visível olig., com o resto da palavra reconstruído por Stroud. 
este termo. O significante é que justamente uma inscrição de 403/2, sobre os ocorridos na derrubada dos Trinta Tiranos, traz pela primeira vez ambos os termos.

Houve então uma relação criada entre leis de Sólon e a democracia pós- Trinta Tiranos. Esta relação produziu uma tradição. Tradição esta onde Sólon e as leis inscritas são intrinsecamente conectadas com a fundação da democracia (DE ROMILLY, 1990).

No entanto, a estrutura desta suposta constituição ancestral democrática gira em torno de um estabelecimento anti-tirânico e de origem oligárquica moderada. A denominação dos trinta oligarcas como os "Trinta Tiranos", bem como a premiação aos assassinos de Frínicus durante o governo dos Quatrocentos como tiranicidas, serve para alinhar o governo, estruturado em contrapartida aos oligarcas, como pertencente a uma tradição antiga de antitirania. Durante as revisões das leis estas são chamadas em seu conjunto como leis de Sólon em sua homenagem, mesmo que muitas das leis vigentes tenham sido compostas décadas após a morte do Sábio ateniense. Esta prática sugere uma continuidade de Sólon e suas propostas anti-tirânicas. A associação entre leis, Sólon, antitirania, oposição às leis não escritas (que apoiavam os oligarcas) e a democracia, levam a uma estruturação justificada por uma inserção em uma tradição ancestral. Esta tradição, formada para justificar as ações e oposições aos oligarcas, dá o tom do que será pela primeira vez organizado conscientemente. A democracia passa a ser uma escolha consciente, anti-tirânica, ligada a leis escritas e, portanto, advindas de Sólon, o legislador anti-tirânico por excelência. Diferente da organização chamada de democracia radical por historiadores modernos, a estrutura de $403 \mathrm{em}$ diante inicia uma tradição que em pouco tempo se verá mais antiga que o próprio Clístenes. Assim, o radicalismo dos oligarcas pavimentou a reação dos demotikoi. Mas foi a estrutura dos Teramistas e sua influência direta que fundamentaram a democracia restaurada de 403. 


\begin{abstract}
This work aims to analyze the historical process that leads to the development of a democratic awareness in Athens at the end of the Fifth century b.C. In order to do that it observes the meanders of a political dispute between oligarchs and their opposition. This dispute is connected with a general desire to end the Peloponesian War, although each group for its own reasons. During this process there is a challenge of ancestry of the proposed, and purported, ancestral constitution of each group. The debate for the right to call their propositions as "the" ancestral constitution ends up entwining with the process of a development of the concept of democracy. From this convergence arose the development of a democratic awareness among the opposition of the oligarchs, the demotikoi.

Keywords: Democracy; Ancestral Constitution; Classical Athens; Oligarchy.
\end{abstract}

\title{
REFERÊNCIAS
}

\section{Documentação Textual}

ARISTÓTELES. A Constituição de Atenas. Trad. Francisco Murari Pires. São Paulo: Editora HUCITEC, 1995.

ARISTOTLE; KENYON, F. G. Aristotle on the Constitution of Athens. 3rd and rev. Union, NJ: Lawbook Exchange, 2003.

TUCÍDIDES. História da Guerra do Peloponeso. Trad. Mário da Gama Kury. 4. Brasília: Editora UnB, 2001.

\section{Bibliografia Geral}

AMEMIYA, Takeshi. Economy and economics of Ancient Greece. London: Routledge, 2007.

ANDREWES, Antony. The Peace of Nicias and the Sicilian Expedition. In: LEWIS, David EDS.;ET AL. (Ed.). The Cambridge Ancient History: Cambridge University Press, v.V, 1992. cap. 10, p.433-462.

BELOCH, Karl. Die attische politik seit Perikles. Leipzig, : B.G. Teubner, 1884. BLAMIRE, Alec. Athenian Finance, 454-404 B.C. Hesperia: The Journal of the American School of Classical Studies at Athens, v. 70, n. 1, p., 2001. Disponível em: < http://www.jstor.org/stable/2668488 > .

BLOCH, Marc. Apologia da história: Ou o ofício de historiador. Zahar, 2002.

BOEGEHOLD, Alan. L. The Establishment of a Central Archive at Athens. American Journal of Archaeology, v. 76, n. 1, p., 1972. Disponível em: < http://www. jstor.org/stable/503608 >.

BUSOLT, Georg. Grieschische geschichte bis zur schlacht bei Chaeroneia. Gotha, : F. A. Perthes, 1893.

Griechische Staatskunde: Hauptteil 1: Handbuch der klassischen Altertumswissenschaft. 3., neugestaltete Aufl. der Griechischen Staats- und Rechtsaltertümer. München: Beck, 1920.

BUTTERFIELD, Herbert. The Englishman and his history. [S.1.]: Cambridge University Press, 1944. 
CAMP, John. M. The archaeology of Athens. New Haven; London: Yale University Press, 2001.

CARAWAN, Edwin. The Athenian Amnesty and the 'Scrutiny of the Laws'. The Journal of Hellenic Studies, v. 122, p., 2002. Disponível em: < http://www.jstor.org/ stable/3246202 >.

. Amnesty and Accoutings for the Thirty. The Classical Quarterly, v. 56, n.

1, p., 2006. Disponível em: < http://www.jstor.org/stable/4493388 >.

CORREAA, Dênis. R. A memória cultural de Sólon de Atenas na aristotélica

'Constituição dos atenienses'. 2012. 111 Dissertação (Mestrado). Programa de Pós-

Graduação em História, Universidade Federal do Rio Grande do Sul - UFRGS, Porto Alegre.

DE ROMILLY, Jacqueline. La mémoire du passé dans la Grèce antique. Revue Historique, v. 283, n. 1 (573), p., 1990. Disponível em: < http://www.jstor.org/ stable/40955338 >.

DE STE CROIX, Geoffrey. E. M. The Constitution of the Five Thousand. Historia, v. 5, p., 1956.

DEVELIN, Robert. Athenian officials 684-321 B.C. Cambridge University Press, 1989.

DIELS, Hermann. et al. I Presocratici: Bompiani Il pensiero occidentale. 1. Milano: Bompiani, 2006.

DIODORUS et al. Diodori Bibliotheca historica: Bibliotheca scriptorum Graecorum et Romanorum Teubneriana. Lipsiae, : In aedibus B. G. Teubneri, 1888.

DOW, Sterling. The Law Codes of Athens. Proceedings of the Massachusetts Historical Society, v. 71, p., 1953. Disponível em: < http://www.jstor.org/ stable $/ 25080473>$.

- The Walls Inscribed with Nikomakhos' Law Code. Hesperia: The Journal of the American School of Classical Studies at Athens, v. 30, n. 1, p., 1961. Disponível em: < http://www.jstor.org/stable/147321 >.

. The Athenian Anagrapheis. Harvard Studies in Classical Philology, v.

67, p., 1963. Disponível em: < http://www.jstor.org/stable/310818 >.

FINGARETTE, Ann. A New Look at the Wall of Nikomakhos. Hesperia: The Journal of the American School of Classical Studies at Athens, v. 40, n. 3, p., 1971. Disponível em: < http://www.jstor.org/stable/147531 >.

FINLEY, Moses. I. The ancestral constitution: an inaugural lecture. London, : Cambridge University Press, 1971.

FORNARA, Charles. W. Evidence for the Date of Herodotus' Publication. The Journal of Hellenic Studies, v. 91, p. 25-34, 1971.

FUKS, Alexander. The ancestral constitution; four studies in Athenian party politics at the end of the fifth century B.C. Westport, Conn., : Greenwood Press, 1971.

GALLIA, Andrew. B. The Republication of Draco's Law on Homicide. The Classical Quarterly, v. 54, n. 2, p., 2004. Disponível em: < http://www.jstor.org/ stable/3556375 >.

GOMME, Arnold. W. ANDREWES, Antony. DOVER, Kenneth. J. An Historical Commentary on Thucydides Volume 4. Books V(25)-VII: An Historical Commentary on Thucydides. Oxford: Oxford University Press, 1970. 
. Commentary on Thucydides Volume 5. Book VIII A Historical Commentary on Thucydides. Oxford: Claredon Press, 1981.

HAMILTON, Charles. D. Spartan Politics and Policy, 405-401 B. C. The American Journal of Philology, v. 91, n. 3, p., 1970. Disponível em: < http://www. jstor.org/stable/292953 >.

HANSEN, Mogens. H. The Athenian Democracy in the Age of Demosthenes : structure, principles, and ideology. Norman: University of Oklahoma Press, 1999.

HARDING, Ph. From the End of the Peloponnesian War to the Battle of Ipsus. Cambridge University Press, 1985.

HARRISON, A. R. W. Law-Making at Athens at the End of the Fifth Century B. C. The Journal of Hellenic Studies, v. 75, p., 1955. Disponível em: < http://www. jstor.org/stable/629166 >.

. Drakon's PROTOS AXON. The Classical Quarterly, v. 11, n. 1, p., 1961. Disponível em: < http://www.jstor.org/stable/637739 >.

HIGNETT, Charles. A history of the Athenian Constitution to the end of the fifth century B.C. Oxford, : Clarendon Press, 1952.

JAMESON, Michael. H. Sophocles and the Four Hundred. Historia: Zeitschrift Alte Geschichte, v. 20, n. 5/6, p., 1971. Disponível em: < http://www.jstor.org/ stable/4435224 >.

JOYCE, Christopher. J. The Athenian Amnesty and Scrunity of 403. The Classical Quarterly (New Series), v. 58, n. 02, p., 2008.

KIRCHNER, Johannes. E. Prosopographia attica. Berolini,:typis et impensis G. Reimeri, 1901.

LAMB, W. R. M.; LYSIAS. Lysias: Loeb classical library. London, New York, : W. Heinemann; G.P. Putnam's Sons, 1930.

LANG, Mabel. Revolution of the 400: Chronology and Constitutions. The American Journal of Philology, v. 88, n. 2, p., 1967. Disponível em: < http://www. jstor.org/stable/293469 >.

LEWIS, David. M. JEFFERY, Lilian. H. ERXLEBEN, Ebeherd. Inscriptiones Atticae Euclidis anno anteriores: IG I³. Editio 3a. Berolini: de Gruyter, 1981.

LIDDEL, Peter. Epigraphy, Legislation and Power Within the Athenian Empire. Bulletin of the Institute of Classical Studies, v. 53, n. 1, p., 2010. Disponível em: < http://dx.doi.org/10.1111/j.2041-5370.2010.00005.x >.

MEIGGS, Russel. LEWIS, David. A Selection of Greek Historical Inscriptions: to the end of the fifth century b.c. Oxford: Claredon Press, 1988.

MOSSÉ, Claude. Comment sélabore un mythe politique: Solon, "père fondateur" de la démocratie athénienne. Annales. Histoire, Sciences Sociales, v. 34, n. 3, p., 1979.

NOEL, Robertson. The Laws of Athens, 410-399 BC: The Evidence for Review and Publication. The Journal of Hellenic Studies, v. 110, p., 1990. Disponível em: < http://www.jstor.org/stable/631732 >.

OSTWALD, Martin. From popular sovereignty to the sovereignty of law : law, society, and politics in fifth-century Athens. Berkeley: University of California Press, 1986.

RHODES, P. J. The Five Thousand in the Athenian Revolutions of 411 b.C. The Journal of Hellenic Studies, v. 92, p., 1972. Disponível em: < http://www.jstor.org/ stable/629977 >. 
. A commentary on the Aristotelian Athenaion politeia. Oxford; New York: Oxford University Press, 1981.

. The Athenian Code of Laws, 410-399 B. C. The Journal of Hellenic

Studies, v. 111, p., 1991. Disponível em: < http://www.jstor.org/stable/631889 >.

U. P., 1993.

. Commentary on the Aristotelian "Athenaion Politeia". 2Rev.ed. Oxf.

ROSS, W. D. Aristotle's Politica. Oxford, Clarendon Press. 1957.

SEALEY, R. Essays in Greek politics. New York, : Manyland Books, 1967.

. Constitutional Changes in Athens in 410 B.C. California Studies in

Classical Antiquity, v. 8, n. ArticleType: research-article / Full publication date: 1975 /,p., 1975.

SICKINGER, James. Literacy, Documents, and Archives in the Ancient Athenian Democracy. The American Archivist, v. 62, n. 2, p., 1999. Disponível em: < http:// www.jstor.org/stable/40294122 >.

SICKINGER, James. P. Public records and archives in classical Athens: Studies in the history of Greece and Rome. Chapel Hill: University of North Carolina Press, 1999.

STODDART, Simon. WHITLEY, James. The social context of literacy in Archaic Greece and Etruria. Visible Language, p. 761, Dez. 1988.

STROUD, Ronald. S. Drakon's Law on homicide. University of California publications: classical studies, v 3. Berkeley, : University of California Press, 1968.

. Greek Inscriptions Theozotides and the Athenian Orphans. Hesperia:

The Journal of the American School of Classical Studies at Athens, v. 40, n. 3, p., 1971. Disponível em: < http://www.jstor.org/stable/147528 >.

. The Gravestone of Socrates' Friend, Lysis. Hesperia: The Journal of the American School of Classical Studies at Athens, v. 53, n. 3, p., 1984.

WILAMOWITZ-MOELLENDORFF, Ulrich. V. Aristoles und Athen. Berlin: Wiedmann, 1893.

WOODHEAD, Arthur. G. Inscriptions: The Decrees. The Athenian Agora, v. 16, p., 1997. Disponível em: < http://www.jstor.org/stable/3601985 >. 